\title{
Radicals in the marine boundary layer during NEAQS 2004: a model study of day-time and night-time sources and sinks
}

\author{
R. Sommariva ${ }^{1,2, *}$, H. D. Osthoff ${ }^{1,2, * *}$, S. S. Brown ${ }^{1}$, T. S. Bates ${ }^{3}$, T. Baynard ${ }^{1,2, * * *}$, D. Coffman ${ }^{3}$, J. A. de Gouw ${ }^{1,2}$, \\ P. D. Goldan ${ }^{2}$, W. C. Kuster ${ }^{1}$, B. M. Lerner ${ }^{1,2}$, H. Stark ${ }^{1,2}$, C. Warneke ${ }^{1,2}$, E. J. Williams ${ }^{1,2}$, F. C. Fehsenfeld ${ }^{2}$, \\ A. R. Ravishankara ${ }^{1}$, and M. Trainer ${ }^{1}$ \\ ${ }^{1}$ Earth System Research Laboratory, NOAA, Boulder, CO, USA \\ ${ }^{2}$ CIRES, University of Colorado, Boulder, CO, USA \\ ${ }^{3}$ Pacific Marine Environment Laboratory, NOAA, Seattle, WA, USA \\ * now at: School of Environmental Sciences, University of East Anglia, Norwich, UK \\ ** now at: Department of Chemistry, University of Calgary, Calgary, Canada \\ **** now at: Lockheed Martin Coherent Technologies, Longmont, CO, USA
}

Received: 10 July 2008 - Published in Atmos. Chem. Phys. Discuss.: 3 September 2008

Revised: 7 April 2009 - Accepted: 6 May 2009 - Published: 13 May 2009

\begin{abstract}
This paper describes a modelling study of several $\mathrm{HO}_{\mathrm{x}}$ and $\mathrm{NO}_{\mathrm{x}}$ species $\left(\mathrm{OH}, \mathrm{HO}_{2}\right.$, organic peroxy radicals, $\mathrm{NO}_{3}$ and $\mathrm{N}_{2} \mathrm{O}_{5}$ ) in the marine boundary layer. A model based upon the Master Chemical Mechanism (MCM) was constrained to observations of chemical and physical parameters made onboard the NOAA ship R/V Brown as part of the New England Air Quality Study (NEAQS) in the summer of 2004. The model was used to calculate $[\mathrm{OH}]$ and to determine the composition of the peroxy radical pool. Modelled $\left[\mathrm{NO}_{3}\right]$ and $\left[\mathrm{N}_{2} \mathrm{O}_{5}\right]$ were compared to in-situ measurements by Cavity Ring-Down Spectroscopy. The comparison showed that the model generally overestimated the measurements by $30-50 \%$, on average.

The model results were analyzed with respect to several chemical and physical parameters, including uptake of $\mathrm{NO}_{3}$ and $\mathrm{N}_{2} \mathrm{O}_{5}$ on fog droplets and on aerosol, dry deposition of $\mathrm{NO}_{3}$ and $\mathrm{N}_{2} \mathrm{O}_{5}$, gas-phase hydrolysis of $\mathrm{N}_{2} \mathrm{O}_{5}$ and reactions of $\mathrm{NO}_{3}$ with NMHCs and peroxy radicals. The results suggest that fog, when present, is an important sink for $\mathrm{N}_{2} \mathrm{O}_{5}$ via rapid heterogeneous uptake. The comparison between the model and the measurements were consistent with values of the heterogeneous uptake coefficient of $\mathrm{N}_{2} \mathrm{O}_{5}\left(\gamma_{\mathrm{N}_{2}} \mathrm{O}_{5}\right)>1 \times 10^{-2}$, independent of aerosol composition in this marine environment. The analysis of the different loss processes of the nitrate radical showed the important role of
\end{abstract}

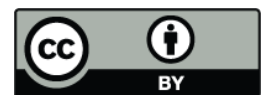

Correspondence to: S. S. Brown

(steven.s.brown@noaa.gov) the organic peroxy radicals, which accounted for a significant fraction (median: $15 \%$ ) of $\mathrm{NO}_{3}$ gas-phase removal, particularly in the presence of high concentrations of dimethyl sulphide (DMS).

\section{Introduction}

Production and loss of radical species control the oxidation of tropospheric trace gases, such as $\mathrm{CO}, \mathrm{CH}_{4}$ and Non Methane Hydrocarbons (NMHCs). The sources of these radicals vary greatly within a diurnal cycle. $\mathrm{OH}$, which is mostly derived from $\mathrm{O}_{3}$ photolysis, is a dominant oxidant during day-time, while $\mathrm{NO}_{3}$ is an important oxidant of certain species during the night. $\mathrm{O}_{3}$ itself serves as an oxidant for some classes of compounds, such as alkenes and dialkenes, at all times of day. In marine environments, atomic chlorine $(\mathrm{Cl})$ may also play a role, though its sources and production rates are less certain.

$\mathrm{NO}_{3}$ is formed by the reaction of ozone and nitrogen dioxide (Reaction R1), but is present in significant concentrations only during the night, since it reacts with $\mathrm{NO}$ and undergoes rapid photolysis (Wayne et al., 1991). $\mathrm{NO}_{3}$ reacts with $\mathrm{NO}_{2}$ in a thermal equilibrium process (R2) to form $\mathrm{N}_{2} \mathrm{O}_{5}$ (Wayne et al., 1991; Osthoff et al., 2007).

$$
\begin{aligned}
\mathrm{NO}_{2}+\mathrm{O}_{3} & \rightarrow \mathrm{NO}_{3}+\mathrm{O}_{2} \\
\mathrm{NO}_{3}+\mathrm{NO}_{2} & \rightleftharpoons \mathrm{N}_{2} \mathrm{O}_{5}
\end{aligned}
$$




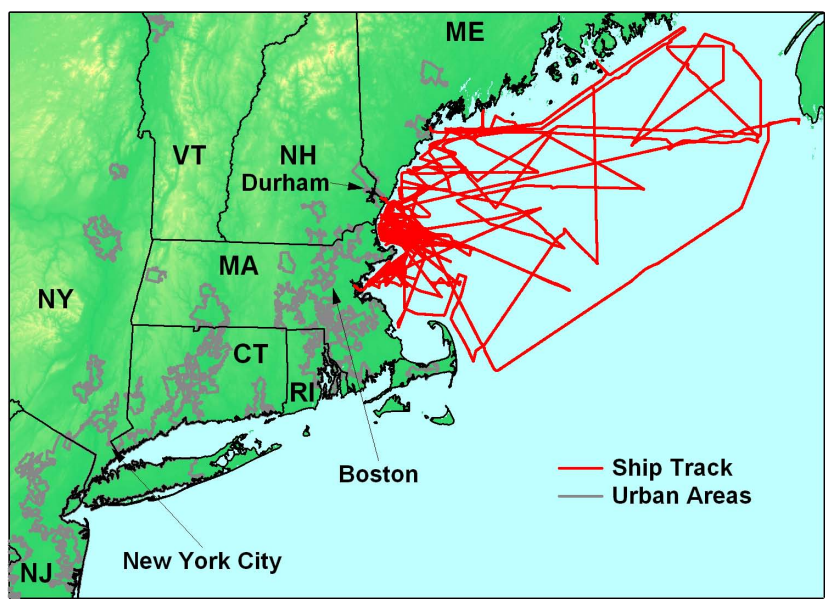

Fig. 1. Map of the Northeast of the United States showing the track of the R/V Brown during the NEAQS 2004 cruise (13 July-12 August).

$\mathrm{NO}_{3}$ reacts mainly with alkenes, aldehydes, some aromatics and dimethyl sulphide (Atkinson and Arey, 2003) to produce peroxy and nitro-peroxy radicals. The subsequent reactions of these peroxy radicals are mainly with $\mathrm{HO}_{2}, \mathrm{RO}_{2}$ and $\mathrm{NO}_{3}$ itself, since NO is generally absent at night (Platt et al., 1990; Allan et al., 2000; Atkinson and Arey, 2003).

Many aspects of night-time chemistry, such as the connection between the $\mathrm{HO}_{\mathrm{x}}$ and $\mathrm{NO}_{3}$ cycles, the interaction between the gas and the aerosol phases and the sinks for $\mathrm{NO}_{3}$ and $\mathrm{N}_{2} \mathrm{O}_{5}$, are still uncertain. The objective of this work was to use a detailed chemical box-model to test the current understanding of the chemical processes in the marine boundary layer at night, with particular attention to the loss processes of $\mathrm{NO}_{3}$ and $\mathrm{N}_{2} \mathrm{O}_{5}$.

This paper presents model calculations of the concentrations of $\mathrm{OH}$ and $\mathrm{NO}_{3}$ from a ship-based field campaign (NEAQS 2004); the main focus of the work was on nighttime radical chemistry, principally $\mathrm{NO}_{3}$ (and, by extension, $\mathrm{N}_{2} \mathrm{O}_{5}$ ), since there were in-situ measurements of these species that could be compared with the model results. This paper also presents calculations of $\mathrm{HO}_{2}$ and organic peroxy radicals $\left(\mathrm{RO}_{2}\right)$ that provide estimates of the concentration of these radicals throughout the campaign.

The NEAQS (New England Air Quality Study) 2004 campaign took place in the Northeast United States during the summer of 2004. It was part of a larger international campaign (International Consortium for Atmospheric Research on Transport and Transformation, ICARTT), the aim of which was to study air quality in the northeastern US and the transport and evolution of pollutants across the North Atlantic. A complete overview of the campaign and of the measurements is presented in Fehsenfeld et al. (2006).

The focus of this work was on the cruise of the NOAA research vessel Ronald H. Brown (R/V Brown), between 13
July and 12 August 2004. The R/V Brown cruised throughout the Gulf of Maine, along the coasts of Massachusetts, New Hampshire, Maine and Nova Scotia and inside Boston harbor (Fig. 1). Both relatively unpolluted air masses from the North Atlantic and polluted air masses from the East coast of the United States and Canada were sampled, as well as biomass burning plumes that had been transported across the North American continent (Warneke et al., 2006).

Section 2 of this paper describes the model. In Sect. 3 the modelled concentrations of $\mathrm{OH}, \mathrm{HO}_{2}$ and $\mathrm{RO}_{2}$ and the composition of the peroxy radical pool are described. In Sect. 4 the model results for $\mathrm{NO}_{3}$ and $\mathrm{N}_{2} \mathrm{O}_{5}$ are compared with the measurements and the discrepancy is investigated. In Sect. 5 the model response to some key uncertainties of the $\mathrm{NO}_{3}$ and $\mathrm{N}_{2} \mathrm{O}_{5}$ loss mechanisms are discussed. In Sect. 6 the gasphase chemistry of $\mathrm{NO}_{3}$ and its interaction with $\mathrm{RO}_{2}$ under different conditions are investigated.

\section{The MCM box-model}

The model was built according to the procedure outlined in Carslaw et al. (1999); Sommariva et al. (2006) using a chemical mechanism taken from the Master Chemical Mechanism (MCM, version 3.1). The MCM is an explicit chemical mechanism for tropospheric chemistry, which contains the detailed degradation schemes of 135 NMHCs, plus an inorganic chemistry mechanism taken from the IUPAC Gas Kinetics Data Evaluation (Atkinson et al., 2003). The mechanism can be downloaded at http://mcm.leeds.ac.uk/ and the details of the MCM can be found in the protocol papers by Jenkin et al. (1997, 2003); Saunders et al. (2003).

In this work, a subset of the MCM containing 88 NMHCs plus $\mathrm{CH}_{4}$ and $\mathrm{CO}$ was used. The dimethyl sulphide (DMS) oxidation mechanism is not included in the MCM, so the same DMS mechanism used in previous work (Carslaw et al., 1999, 2002; Sommariva et al., 2004, 2006) was added to the model. This DMS mechanism is based upon the works of Yin et al. (1990a,b); Koga and Tanaka (1993); Turnipseed et al. (1996) with many of the rate coefficients updated as in Jenkin et al. (1996).

In addition to the gas-phase mechanism, the model included uptake of gas-phase species on aerosol. The uptake of a gas molecule on a particle is described by Eq. (1) (Fuchs and Sutugin, 1970):

$$
\begin{aligned}
k_{\text {het }} & =\frac{N \pi r^{2} \bar{c} \gamma}{1+\gamma\left[\frac{0.75+0.2983 K_{n}}{K_{n}\left(K_{n}+1\right)}\right]} \\
& \simeq N \pi r^{2} \bar{c} \gamma=\frac{A}{4} \bar{c} \gamma
\end{aligned}
$$

where $N$ is the particle number density, $r$ is the particle radius $(\mu \mathrm{m}), \bar{c}$ is the mean molecular speed of the gas $\left(\mathrm{cm} \mathrm{s}^{-1}\right)$, $\gamma$ is the uptake coefficient and $K_{n}=\frac{\lambda}{r}$ is the Knudsen number ( $\lambda$ is the mean free path of the gas in $\mu \mathrm{m}$ ). When the particle radius is much smaller than the mean free path of the 
gas $\left(K_{n} \rightarrow \infty\right)$, Eq. (1) can be approximated to Eq. (2), where $A$ is the total aerosol surface area density $\left(\mu \mathrm{m}^{2} \mathrm{~cm}^{-3}\right)$. This approximation is valid when most of the aerosol surface area is in the sub-micron fraction, which was the case during the R/V Brown cruise (Quinn et al., 2006). Heterogeneous uptake of 34 gas-phase species was assumed to be irreversible and calculated using Eq. (2). For some species, a value of $\gamma$ could not be found in the literature, so the mass accommodation coefficient $(\alpha)$, which takes into account only the accommodation component of the uptake process, was used instead (Carslaw et al., 1999, 2002; Sommariva et al., 2004, 2006).

The model also included dry deposition terms $\left(k=V_{d} / h\right.$, where $V_{d}$ is the deposition velocity in $\mathrm{cm} \mathrm{s}^{-1}$ and $h$ is the boundary layer height in $\mathrm{cm}$ ) for $\mathrm{O}_{3}, \mathrm{NO}_{2}, \mathrm{SO}_{2}, \mathrm{HNO}_{3}$, hydroperoxides, organic nitrates and carbonyls, as in previous MCM models (Carslaw et al., 1999, 2002; Sommariva et al., 2004, 2006). The boundary layer height was set to a constant $100 \mathrm{~m}$ for the entire campaign, based on sonde measurements made onboard the R/V Brown (Angevine et al., 2006).

The model was constrained to the measured values of $\mathrm{CO}$, $\mathrm{CH}_{4}, \mathrm{NO}, \mathrm{NO}_{2}, \mathrm{O}_{3}, \mathrm{SO}_{2}, \mathrm{H}_{2} \mathrm{O}, 88 \mathrm{NMHCs}, j\left(\mathrm{O}^{1} \mathrm{D}\right), j\left(\mathrm{NO}_{2}\right)$, $j\left(\mathrm{NO}_{3}\right)$, temperature, pressure, sun declination, latitude and longitude. The total aerosol surface area was calculated from the aerosol number-size distributions in the diameter range of $0.02-10 \mu \mathrm{m}$ measured at relative humidity (RH) of $60 \%$ and corrected with a calculated RH-dependent growth factor (Tang, 1997; Cruz and Pandis, 2000).

Methane, formaldehyde and molecular hydrogen were not measured on the R/V Brown during NEAQS 2004. Measurements of $\mathrm{CH}_{4}$ taken at the University of New Hampshire Observing Station at Thompson Farm (near Durham, $\mathrm{NH}$, close to the study area; Fig. 1) were used in the model. During the period of the campaign, the average $\left[\mathrm{CH}_{4}\right]$ measured at Thompson Farm was 1869.3 \pm 85.2 ppb. Formaldehyde was estimated using a relationship with measured acetaldehyde $\left(1.25 \times\left[\mathrm{CH}_{3} \mathrm{CHO}\right]+0.46\right.$, with $\mathrm{CH}_{3} \mathrm{CHO}$ in $\left.\mathrm{ppb}\right)$ based upon the measurements in a marine environment by Still et al. (2006). $\left[\mathrm{H}_{2}\right]$ was set to a representative Northern Hemisphere concentration of $500 \mathrm{ppb}$ (Heard et al., 2006). Most of the NMHCs were measured by Gas Chromatography coupled with Mass Spectrometry (GC-MS, Goldan et al., 2004) and some oxygenated compounds (such as acetic acid) by Proton Transfer Mass Spectrometry (PIT-MS, Warneke et al., 2005). Since the GC-MS could not resolve all the isomers of xylenes and ethyl-methyl-benzenes, the ratio between $\mathrm{m}$-xylene and $\mathrm{p}$-xylene and the ratio between 1 ethyl-3-methyl-benzene and 1-ethyl-4-methyl-benzene were assumed to be 1:1. Test model runs showed that the assumptions and estimates on the concentrations of $\mathrm{CH}_{4}, \mathrm{H}_{2}$, $\mathrm{HCHO}$, xylenes and ethyl-methyl-benzenes did not affect the concentrations of the species of interest $\left(\mathrm{OH}, \mathrm{HO}_{2}, \mathrm{RO}_{2}\right.$, $\mathrm{NO}_{3}, \mathrm{~N}_{2} \mathrm{O}_{5}$ ) in a significant way. The largest impact was observed on day-time species and was due to methane and formaldehyde: under the conditions of NEAQS 2004, chang- ing $\left[\mathrm{CH}_{4}\right]$ by $\pm 10 \%$ resulted, on average, in a variation of $<3 \%$ for $\mathrm{OH}$ and $\mathrm{CH}_{3} \mathrm{O}_{2}$, while changing [HCHO] by $\pm 10 \%$ resulted in a variation of $<2 \%$ for $\mathrm{OH}$ and $<5 \%$ for $\mathrm{HO}_{2}$.

The photolysis rates of $\mathrm{HONO}, \mathrm{HNO}_{3}, \mathrm{H}_{2} \mathrm{O}_{2}, \mathrm{CH}_{3} \mathrm{OOH}$, $\mathrm{HCHO}, \mathrm{CH}_{3} \mathrm{CHO}$ and $\mathrm{CH}_{3} \mathrm{COCH}_{3}$ were calculated using empirical correlations with other measured photolysis rates. Parameters for these specific photolysis rates were developed by comparing a linear combination of $j\left(\mathrm{NO}_{2}\right)$ and $j\left(\mathrm{O}^{1} \mathrm{D}\right)$ to the photolysis rates calculated from measured actinic flux, literature absorption spectra and quantum yields, as most absorption spectra of photochemically important molecules are spectrally located between the regions where $\mathrm{O}_{3}$ and $\mathrm{NO}_{2}$ photolyze (H. Stark, personal communication).

The GC-MS sampled for 5 min every half an hour. All the other model constraints were averaged over $5 \mathrm{~min}$ every $30 \mathrm{~min}$, so that all model inputs had the same frequency of the GC-MS data. Since radicals are short-lived, their concentrations are determined by the in-situ strengths of their sources and sinks rather than by transport. This assumption is valid for ground-based measurements and for platforms moving at slow speeds, such as a ship. Hence, the concentrations of radicals were calculated every $30 \mathrm{~min}$ from the measured variables and from the concentrations of the intermediate species, calculated at each step starting from their value on the previous step. The model was integrated using the FACSIMILE software package (http://www.mcpa-software. $\mathrm{com} /$ ).

The model was used to calculate $[\mathrm{OH}],\left[\mathrm{HO}_{2}\right]$ and organic peroxy radicals $\left(\mathrm{RO}_{2}\right)$, none of which were measured during the campaign, and to calculate $\left[\mathrm{NO}_{3}\right]$ and $\left[\mathrm{N}_{2} \mathrm{O}_{5}\right]$, which were compared to the in-situ measurements by Cavity Ring-Down Spectroscopy (CaRDS, Dubé et al., 2006; Osthoff et al., 2006). The model results and the explicit chemistry of the MCM were then used to study the response of modelled $\mathrm{NO}_{3}$ and $\mathrm{N}_{2} \mathrm{O}_{5}$ to several key kinetic parameters and to analyze the sinks of $\mathrm{NO}_{3}$ and $\mathrm{N}_{2} \mathrm{O}_{5}$, as described in the following sections.

\section{Modelled concentrations of $\mathrm{OH}, \mathrm{HO}_{2}$ and $\mathrm{RO}_{2}$}

Since $\mathrm{OH}$ is the dominant day-time oxidant, an estimate of its concentration is critical to the interpretation of field measurements of other trace gases. Direct measurements of $\mathrm{OH}$ were not available from the set of instruments on the R/V Brown during NEAQS 2004. The concentrations of $\mathrm{OH}$, together with the concentrations of $\mathrm{HO}_{2}$ and $\mathrm{RO}_{2}$, were calculated for the 26 days of the R/V Brown cruise using the MCM model. These calculations serve to provide estimates for hydroxyl and peroxy radical levels, but also as a comparison to another, simpler parametrization that has been used in previous studies to calculate ambient $\mathrm{OH}$ in the absence of measurements. 

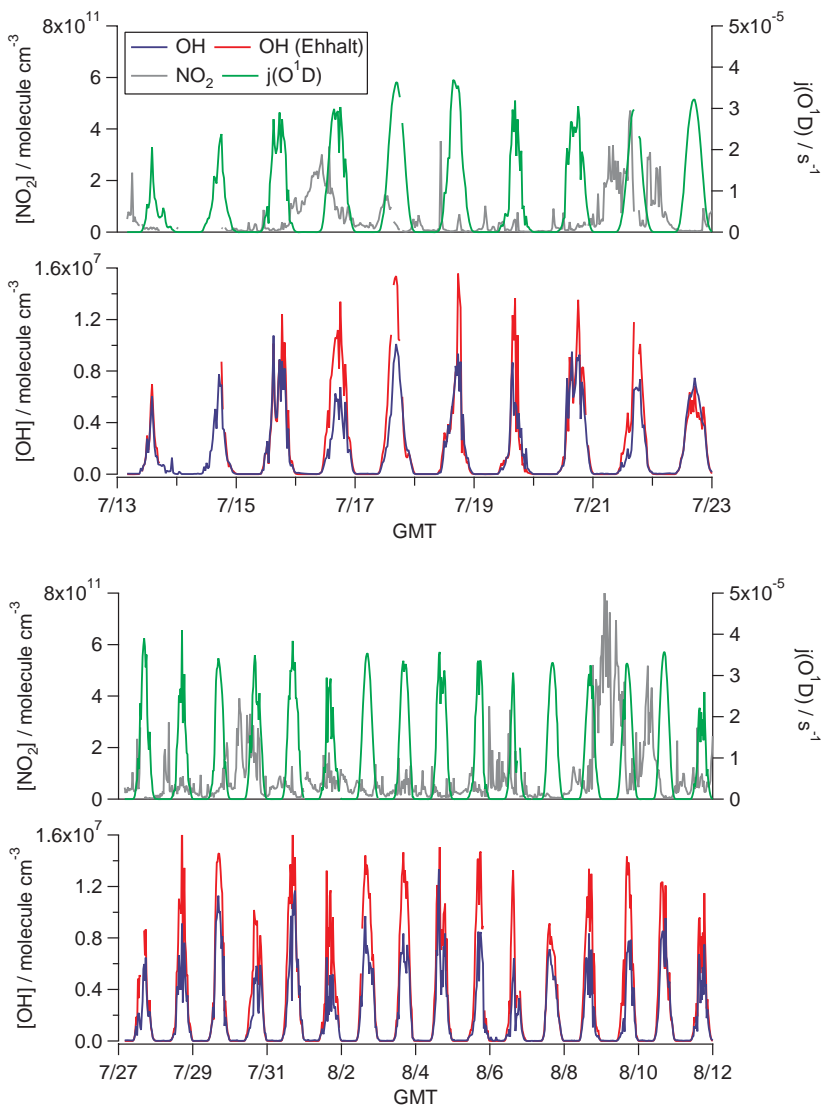

Fig. 2. Measured $\mathrm{O}_{3}$ photolysis rates and $\mathrm{NO}_{2}$ (top graphs) together with modelled and parametrized $\mathrm{OH}$ (bottom graphs) during the R/V Brown cruise.

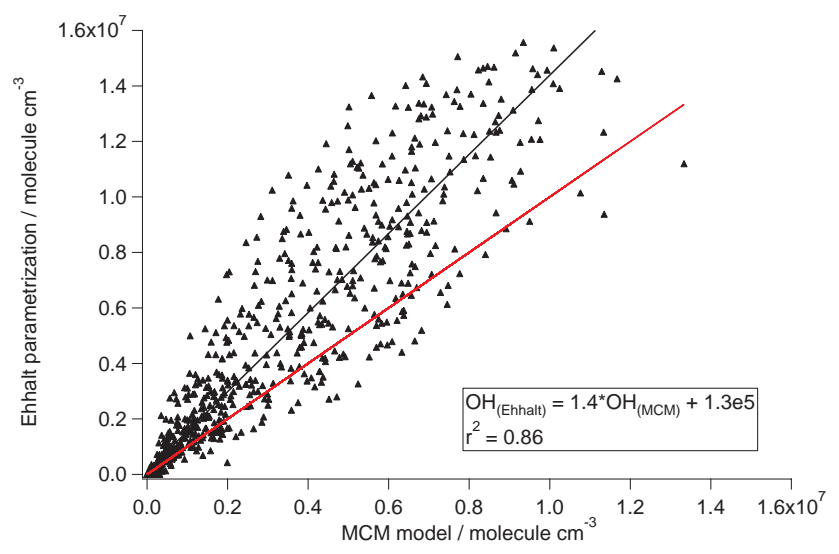

Fig. 3. $[\mathrm{OH}]$ calculated with the Ehhalt parametrization vs. $[\mathrm{OH}]$ calculated with the MCM model. The black line is the fit and the red line is $1: 1$.

\section{$3.1 \mathrm{OH}$}

Several approaches, besides the use of box-models, have been developed to estimate the concentration of $\mathrm{OH}$ in the absence of measurements. Carslaw et al. (2000) derived a steady-state solution for $\mathrm{OH}$ and $\mathrm{HO}_{2}$ from a reduced boxmodel and similar steady-state methods have been used by other groups (see Savage et al., 2001, and references therein). A simpler approach is to use a linear relationship between $[\mathrm{OH}]$ and the solar zenith angle (Hanisco et al., 2001) or with $j\left(\mathrm{O}^{1} \mathrm{D}\right)$ (see Rohrer and Berresheim, 2006, and references therein). Ehhalt and Rohrer (2000) proposed a more sophisticated parametrization involving $j\left(\mathrm{O}^{1} \mathrm{D}\right), j\left(\mathrm{NO}_{2}\right)$ and $\left[\mathrm{NO}_{2}\right]$, based on the measurements made during the POPCORN (Plant Emitted Compounds and $\mathrm{OH}$ Radicals in Northeastern Germany) 1994 campaign in a remote rural site in Germany:[2mm]

$[\mathrm{OH}]=a j\left(\mathrm{O}^{1} \mathrm{D}\right)^{\alpha} j\left(\mathrm{NO}_{2}\right)^{\beta} \frac{b\left[\mathrm{NO}_{2}\right]+1}{c\left[\mathrm{NO}_{2}\right]^{2}+d\left[\mathrm{NO}_{2}\right]+1}$

[2mm] where $a, b, c, d, \alpha$ and $\beta$ are empirical parameters derived by fitting Eq. (3) to the observations. Although the Ehhalt parametrization was not intended to provide a calculation of $\mathrm{OH}$ valid for all environments, it has often been used as such because of its simplicity. For example, it has been used for data interpretation during previous studies (e.g. Warneke et al., 2004; Ambrose et al., 2007; Stark et al., 2007). Models based on the MCM in past studies (e.g. Carslaw et al., 1999; Sommariva et al., 2004, 2006) typically showed agreement with measurements in the MBL and have been able to reproduce measured $[\mathrm{OH}]$ to within $40 \%$. A previous study with a similar model showed that constraining the model to measured acetaldehyde, methanol and acetone resulted in better agreement with measured OH (Sommariva et al., 2006). In this work, the "base" model was constrained to 9 additional oxygenated compounds (acetic acid, ethanol, i-propanol, propanal, butanal, pentanal, methyl ethyl ketone, methacrolein and methyl vinyl ketone), which should further improve the model performance. The estimated uncertainty of the model for $\mathrm{OH}$ is $30-40 \%$ (Sommariva et al., 2004).

The use of a detailed model constrained to the in-situ measurements of other atmospheric components should, in principle, give a more precise estimate of the $\mathrm{OH}$ concentration than an empirical parametrization (e.g. Ehhalt, Eq. 3), especially in environments with different conditions from those upon which the parametrization has been derived (e.g. the POPCORN campaign, in an environment that was comparatively unpolluted but rich in biogenic compounds). In the absence of measurements, it is not possible to definitively assess the accuracy of either the calculation or the parametrization. However, the comparison with the results of a detailed chemical model can give some measure of the parametrization's reliability. $[\mathrm{OH}]$ calculated with the Ehhalt parametrization is shown in Fig. 2 together with $[\mathrm{OH}]$ calculated by the MCM model. While occasionally lower than 


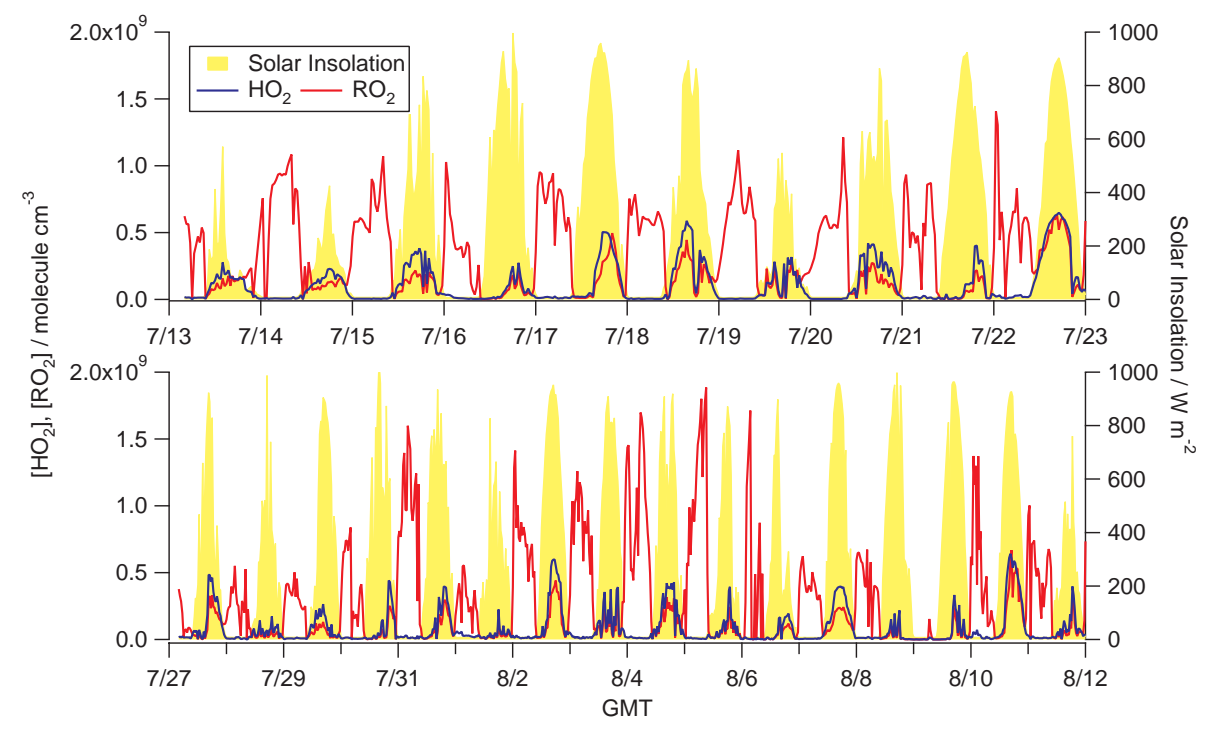

Fig. 4. Modelled $\mathrm{HO}_{2}$ and $\mathrm{RO}_{2}$ during the $\mathrm{R} / \mathrm{V}$ Brown cruise.

the modelled $\mathrm{OH}$ (such as on 22 July), parameterized $\mathrm{OH}$ was typically higher than modelled $\mathrm{OH}$, by about $20-40 \%$ (Fig. 3).

\section{2 $\mathrm{HO}_{2}$ and $\mathrm{RO}_{2}$}

Modelled concentrations of peroxy radicals $\left(\mathrm{HO}_{2}\right.$ and $\left.\mathrm{RO}_{2}\right)$ are shown in Fig. 4. The composition of the total peroxy radical pool $\left(\mathrm{HO}_{2}+\mathrm{RO}_{2}\right)$ changed throughout the cruise and was different during the day and the night because of the different sources, formation and loss mechanisms of these radicals. The two most abundant peroxy radicals were typically $\mathrm{HO}_{2}$ and $\mathrm{CH}_{3} \mathrm{O}_{2}$. Figure 5 shows the fraction of $\mathrm{HO}_{2}$ and $\mathrm{CH}_{3} \mathrm{O}_{2}$ in the total peroxy radical pool $\left(\mathrm{HO}_{2}+\mathrm{RO}_{2}\right)$. On average, during the day $\mathrm{HO}_{2}$ accounted for about $50-70 \%$ and $\mathrm{CH}_{3} \mathrm{O}_{2}$ for about $20 \%$ of total peroxy radicals. At night, $\mathrm{HO}_{2}$ accounted for only $10 \%$ or less of total peroxy radicals, while $\mathrm{CH}_{3} \mathrm{O}_{2}$ for about 20-30\% of total peroxy radicals (Fig. 5), due to the faster decay of $\mathrm{HO}_{2}$ in the absence of $\mathrm{NO}$ (the rate coefficient of $\mathrm{HO}_{2}+\mathrm{HO}_{2}$ is approximately 7 times larger than the rate coefficient of $\mathrm{CH}_{3} \mathrm{O}_{2}+\mathrm{CH}_{3} \mathrm{O}_{2}$ ).

The modelled organic peroxy radical $\left(\mathrm{RO}_{2}\right)$ pool was composed of 795 organic peroxy radicals and was complex and variable, depending on the concentrations of the different NMHCs precursors. The single most important component was always $\mathrm{CH}_{3} \mathrm{O}_{2}$ (Fig. 5). During the day, $\mathrm{CH}_{3} \mathrm{O}_{2}$ accounted for $30-60 \%$ of the organic peroxy radicals, while at night it accounted for $20-40 \%$.

The most important formation pathways of $\mathrm{CH}_{3} \mathrm{O}_{2}$ during the day were the reactions of $\mathrm{CH}_{4}$ with $\mathrm{OH}$ and of $\mathrm{CH}_{3} \mathrm{C}(\mathrm{O}) \mathrm{O}_{2}$ (mostly from acetaldehyde reaction with $\mathrm{OH}$ ) with $\mathrm{NO}$, which together typically accounted for about $80 \%$ of the total day-time production of $\mathrm{CH}_{3} \mathrm{O}_{2}$. The relative importance of these two reactions was variable, with some days
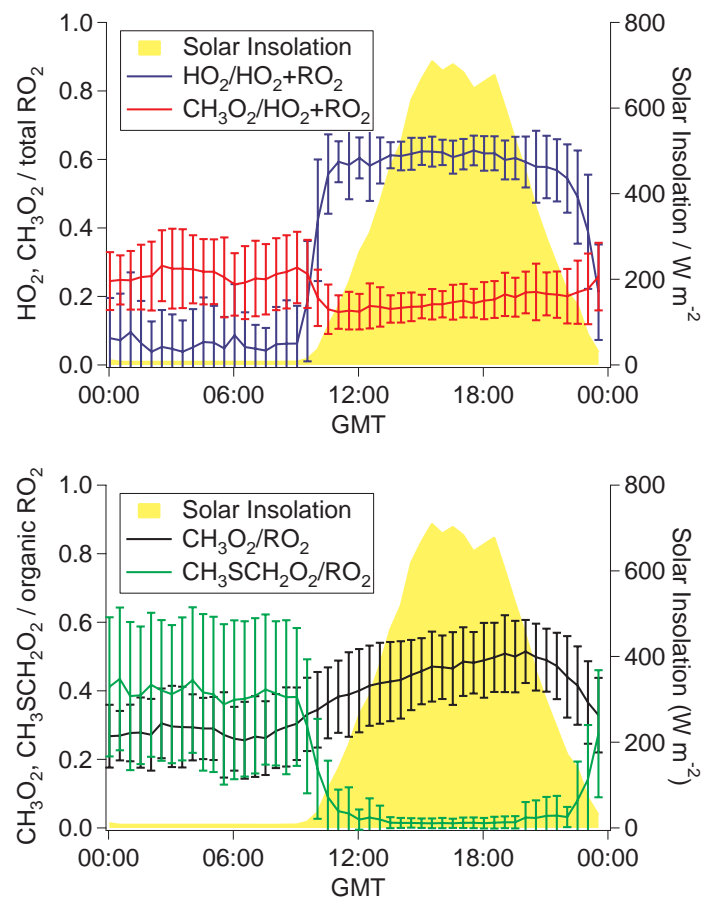

Fig. 5. Diurnally averaged modelled fractions of $\mathrm{HO}_{2}, \mathrm{CH}_{3} \mathrm{O}_{2}$ in total peroxy radicals $\left(\mathrm{HO}_{2}+\mathrm{RO}_{2}\right)$ and of $\mathrm{CH}_{3} \mathrm{O}_{2}, \mathrm{CH}_{3} \mathrm{SCH}_{2} \mathrm{O}_{2}$ in organic peroxy radicals $\left(\mathrm{RO}_{2}\right)$ during the $\mathrm{R} / \mathrm{V}$ Brown cruise. The error bars are $1-\sigma$.

when either one contributed up to a factor of 2 more than the other and other days when the two reactions contributed almost equally to the formation of $\mathrm{CH}_{3} \mathrm{O}_{2}$. Another major contribution was the decomposition of the methylsulphonyl radical $\left(\mathrm{CH}_{3} \dot{\mathrm{SO}}_{2}\right)$, a product of DMS oxidation (Barnes et al., 

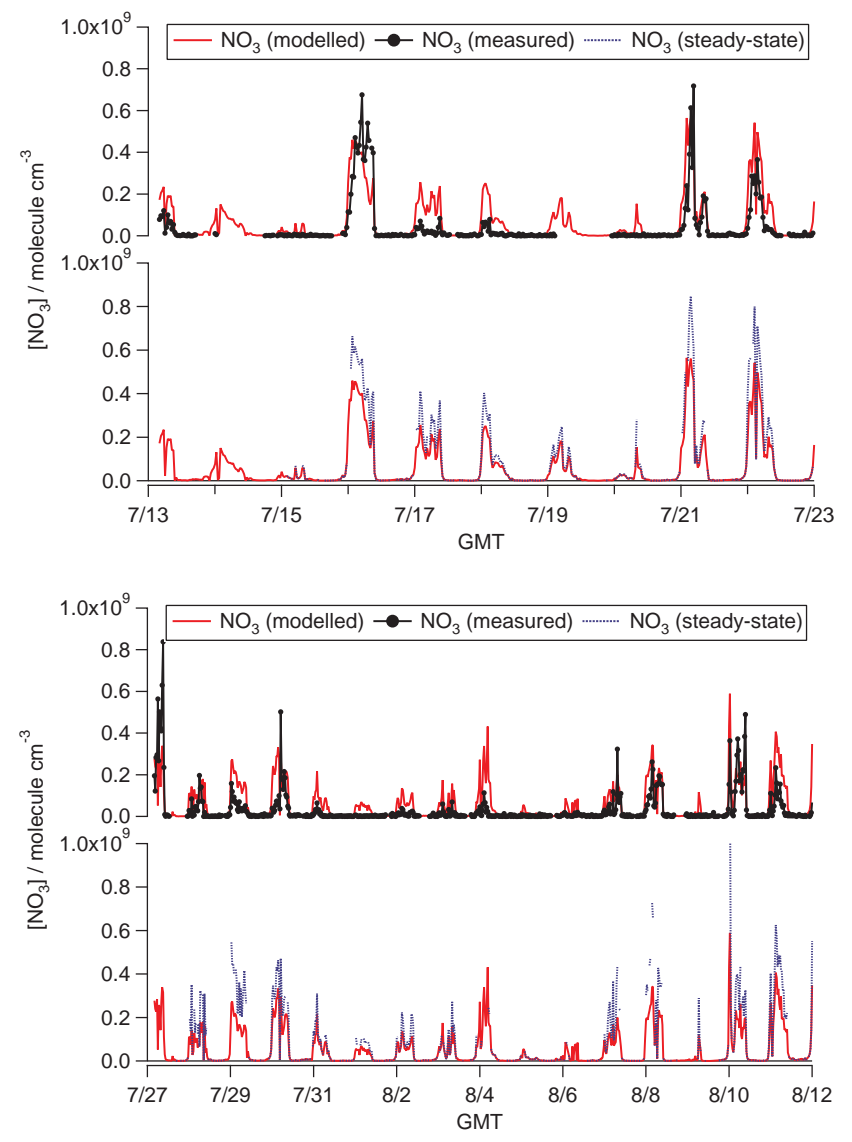

Fig. 6. Modelled ("base" model) and measured $\mathrm{NO}_{3}$ concentrations (top graphs), modelled and calculated (with the steady-state expression, Eq. 4) $\mathrm{NO}_{3}$ concentrations (bottom graphs) during the $\mathrm{R} / \mathrm{V}$ Brown cruise.

2006), which could account for up to $10 \%$ of the total daytime $\mathrm{CH}_{3} \mathrm{O}_{2}$ production rate. During the night, this route was the single most important formation pathway for $\mathrm{CH}_{3} \mathrm{O}_{2}$, and accounted for almost all of $\mathrm{CH}_{3} \mathrm{O}_{2}$ production on the nights with large DMS concentrations.

Besides $\mathrm{CH}_{3} \mathrm{O}_{2}$, the composition of the $\mathrm{RO}_{2}$ pool reflected the relative concentrations of anthropogenic or biogenic compounds. Since the measurements were taken in a marine environment, the products of the nocturnal oxidation of DMS, the most important of which was the $\mathrm{CH}_{3} \mathrm{SCH}_{2} \mathrm{O}_{2}$ radical, were always significant contributors to the organic radical pool. During the day $\mathrm{CH}_{3} \mathrm{SCH}_{2} \mathrm{O}_{2}$ was a minor component of the $\mathrm{RO}_{2}$ pool, less than $5 \%$, but during the night it often accounted for a large fraction of the organic peroxy radicals (20-60\%, Fig. 5). The composition of the peroxy radical pool during some selected nights will be discussed in detailed in Sect. 6, in relation with the chemistry of the nitrate radical.
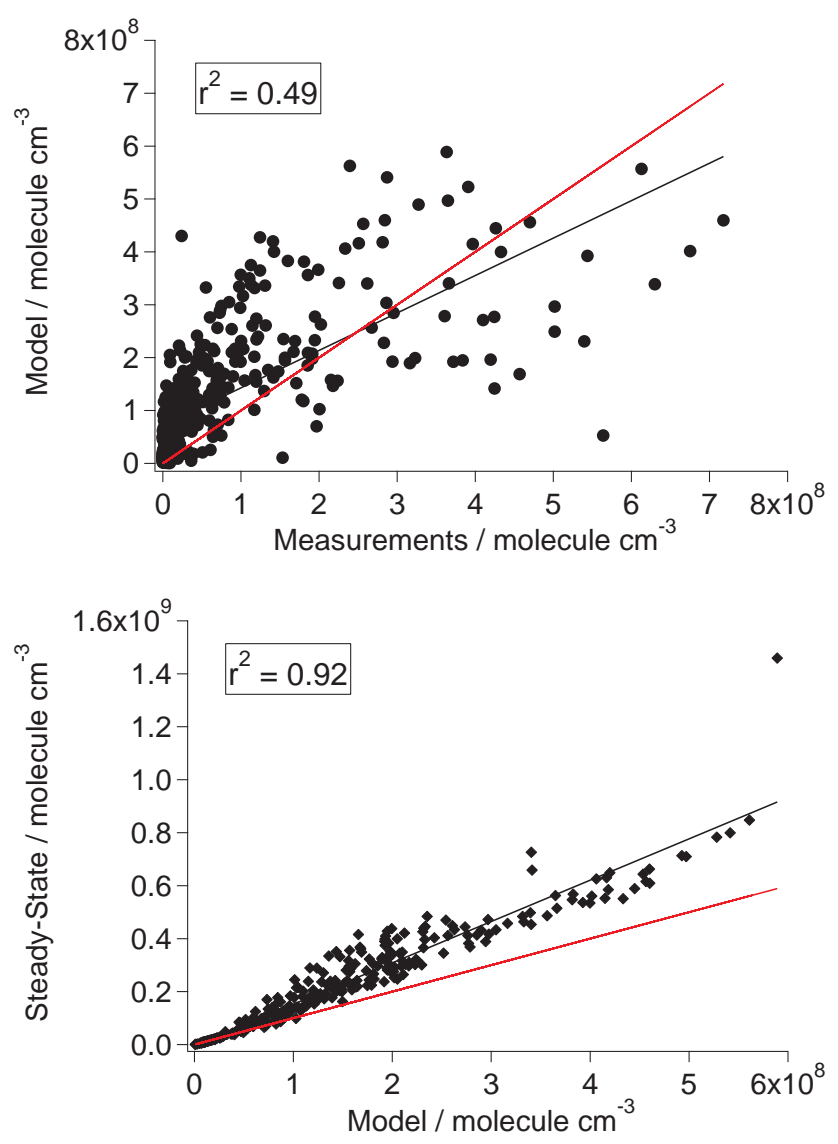

Fig. 7. Modelled vs. measured and calculated (with the steadystate expression, Eq. 4) vs. modelled $\mathrm{NO}_{3}$ concentrations during the R/V Brown cruise. The black lines are the fits and the red lines are $1: 1$.

\section{Modelled and measured concentrations of $\mathrm{NO}_{3}$ and $\mathrm{N}_{2} \mathrm{O}_{5}$}

In-situ measurements of $\mathrm{NO}_{3}$ and $\mathrm{N}_{2} \mathrm{O}_{5}$ by Cavity RingDown Spectroscopy (CaRDS) were taken onboard the R/V Brown (Osthoff et al., 2006, 2009). Measurements taken with a similar instrument during a previous campaign in the same area (NEAQS 2002) could be compared only to the results of a steady-state model, described further below (Aldener et al., 2006). Here, we compare the measurements of $\mathrm{NO}_{3}$ and $\mathrm{N}_{2} \mathrm{O}_{5}$ to the results of the MCM model for all the 27 nights of the cruise.

\subsection{Model-measurements comparison}

The modelled and measured concentrations of $\mathrm{NO}_{3}$ during the NEAQS 2004 R/V Brown cruise are shown in Fig. 6. The agreement between the model and the measurements was variable, although the model overestimated the measured concentrations of $\mathrm{NO}_{3}$ and $\mathrm{N}_{2} \mathrm{O}_{5}$ by $30-50 \%$, on average. Modelled and measured $\mathrm{N}_{2} \mathrm{O}_{5}$ showed the same 
level of agreement as $\mathrm{NO}_{3}$. Although the model tended in general to reproduce the measured level of $\mathrm{NO}_{3}$ on many nights (Fig. 6), the correlation between the model and the measurements was rather poor $\left(r^{2}=0.49\right)$. The scatter plot in Fig. 3.2 clearly shows that the ratio between the model and the measurement was not constant and was higher at lower concentrations of $\mathrm{NO}_{3}\left(<2 \times 10^{8}\right.$ molecule $\left.\mathrm{cm}^{-3}\right)$. At higher concentrations, the ratio between the model and the measurements was closer to one, but the data were very scattered, indicating that the model did not always reproduce the variation in the observations.

While the reasons for the lack of correlation are not entirely clear, one potential issue is the vertical stratification within the shallow $(100 \mathrm{~m})$ nocturnal marine boundary layer. Under such conditions, vertical gradients and transport might play an important role (Jones et al., 2005), as demonstrated, for example, in the one-dimensional modelling work by (Geyer and Stutz, 2004). Such vertical gradients could lead to differences between the zero-dimensional MCM model and the measured $\mathrm{NO}_{3}$ and $\mathrm{N}_{2} \mathrm{O}_{5}$. The zero-dimensional model assumed that the air within this boundary layer was mixed on the time scale of the chemical transformation of the relevant species. We note only that zero-dimensional approaches have been successful in describing $\mathrm{NO}_{\mathrm{x}}$ loss budgets and $\mathrm{NO}_{3}$ and $\mathrm{N}_{2} \mathrm{O}_{5}$ sink budgets in previous analyses of field measurements from the same region (Brown et al., 2004; Aldener et al., 2006).

On some nights (e.g. 15, 18, 19, 20 July and 1, 4, 5, 6, 9 August) the measurements of $\mathrm{NO}_{3}$ were below the detection limit of the instrument $\left(2.6 \times 10^{7}\right.$ molecule $\left.\mathrm{cm}^{-3}\right)$. The model, however, calculated concentration of $\mathrm{NO}_{3}$ up to an order of magnitude higher than the instrument's detection limit (Fig. 6). On many of these nights, fog was present. An estimate of the fog surface area was made using observations from the Aerosol Extinction Cavity Ring-Down Spectrometer (Baynard et al., 2007). The uptake rates of $\mathrm{NO}_{3}$ and $\mathrm{N}_{2} \mathrm{O}_{5}$ on fog droplets were calculated with Eq. (1) assuming a monodisperse distribution of droplets with radius of $7.5 \mu \mathrm{m}$ and using uptake coefficients $(\gamma)$ of $\mathrm{NO}_{3}$ and $\mathrm{N}_{2} \mathrm{O}_{5}$ on pure water droplets $(0.0002$ and 0.04 , respectively Rudich et al., 1996; VanDoren et al., 1990). The model was then run with the additional constraint of uptake of $\mathrm{NO}_{3}$ and $\mathrm{N}_{2} \mathrm{O}_{5}$ on fog ("fog" model in Fig. 8).

Figure 8 shows the impact of fog on modelled $\mathrm{NO}_{3}$ on the night of 29 July. The "fog" model was able to reproduce the measurements, while the "base" model overestimated them by up to $80 \%$ (Fig. 8). The impact of fog on modelled $\left[\mathrm{NO}_{3}\right]$ was mostly driven by the uptake of $\mathrm{N}_{2} \mathrm{O}_{5}$ on the fog droplets. As already noted by Osthoff et al. (2006), the uptake of $\mathrm{N}_{2} \mathrm{O}_{5}$ on fog droplets was extremely rapid and, because of the difference in the uptake coefficients, about two orders of magnitude faster than the uptake of $\mathrm{NO}_{3}$. The estimated fog surface area was up to $5 \times 10^{5} \mu \mathrm{m}^{2} \mathrm{~cm}^{-3}$ and the effective pseudo first-order rate coefficient for the uptake of $\mathrm{N}_{2} \mathrm{O}_{5}$ on fog droplets (Eq. 1) was up to $1.5 \mathrm{~s}^{-1}$. While our estimate

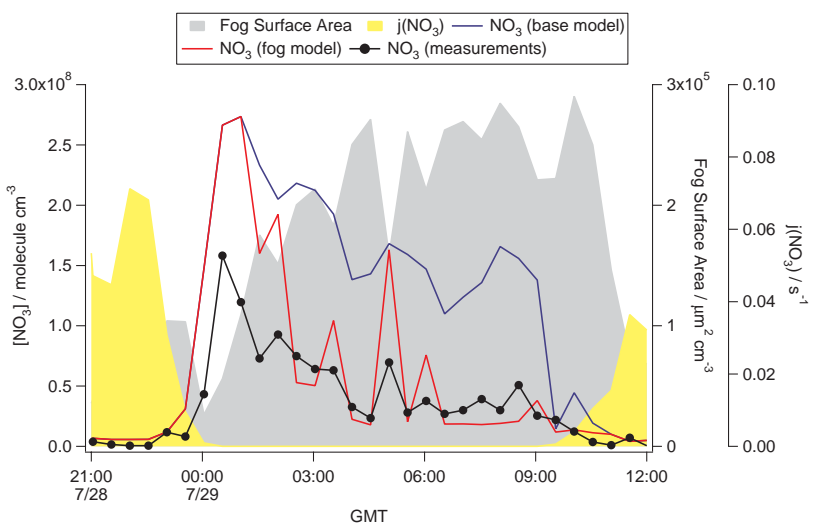

Fig. 8. Modelled ("base" and "fog" model) and measured $\mathrm{NO}_{3}$ on 29 July and fog surface area calculated assuming monodisperse droplets with a radius of $7.5 \mu \mathrm{m}$.

of the fog surface area is quite uncertain, the uptake on fog droplets would still be much faster than all the other loss processes for $\mathrm{N}_{2} \mathrm{O}_{5}$ for even a factor of 2-3 change in the estimated fog surface area.

One potential reason for the discrepancy between the model and the measurements is that the modelling approach (Sect. 2) might not be suitable for species with relatively long lifetimes, such as $\mathrm{NO}_{3}$ and $\mathrm{N}_{2} \mathrm{O}_{5}$. If the time bewteen two consecutive model inputs ( $30 \mathrm{~min}$ ) was not enough to allow $\mathrm{NO}_{3}$ and $\mathrm{N}_{2} \mathrm{O}_{5}$ to reach a steady-state, the model results would not be reliable. In order to investigate this issue, the concentrations of $\mathrm{NO}_{3}$ and $\mathrm{N}_{2} \mathrm{O}_{5}$ calculated with the MCM model were compared to the concentrations calculated by assuming a steady-state with respect to the production and loss of the two species.

The steady-state expressions (Eq. 4 , where $k_{\mathrm{NO}_{3}}$ and $k_{\mathrm{N}_{2} \mathrm{O}_{5}}$ are the effective pseudo first-order rate coefficients for the $\mathrm{NO}_{3}$ and $\mathrm{N}_{2} \mathrm{O}_{5}$ sinks and $K_{e q}$ is the equilibrium constant of Reaction R2) have been discussed previously in Brown et al. (2003a) and the details of the steady-state calculations made for the R/V Brown NEAQS cruise can be found in Osthoff et al. (2006). It is important to note that the steady-state calculations used only measured NMHCs to calculate the sinks of $\mathrm{NO}_{3}\left(k_{\mathrm{NO}_{3}}\right)$ and, therefore, deviations from the steadystate are expected when part of the $\mathrm{NO}_{3}$ reactivity was due to second-generation oxidation products not measured on the R/V Brown.

$$
\begin{aligned}
{\left[\mathrm{NO}_{3}\right]_{s s} } & =\frac{k_{3}\left[\mathrm{NO}_{2}\right]\left[\mathrm{O}_{3}\right]}{k_{\mathrm{NO}_{3}}+k_{\mathrm{N}_{2} \mathrm{O}_{5}} K_{e q}\left[\mathrm{NO}_{2}\right]} \\
{\left[\mathrm{N}_{2} \mathrm{O}_{5}\right]_{s s} } & =K_{e q}\left[\mathrm{NO}_{2}\right]\left[\mathrm{NO}_{3}\right]_{s s}
\end{aligned}
$$

The steady-state approach has been widely used in previous studies to interpret the measurements of $\mathrm{NO}_{3}$ and $\mathrm{N}_{2} \mathrm{O}_{5}$ (e.g. Platt et al., 1984; Allan et al., 1999, 2000; Brown et al., 2003b; Vrekoussis et al., 2004; Aldener et al., 2006) and the 

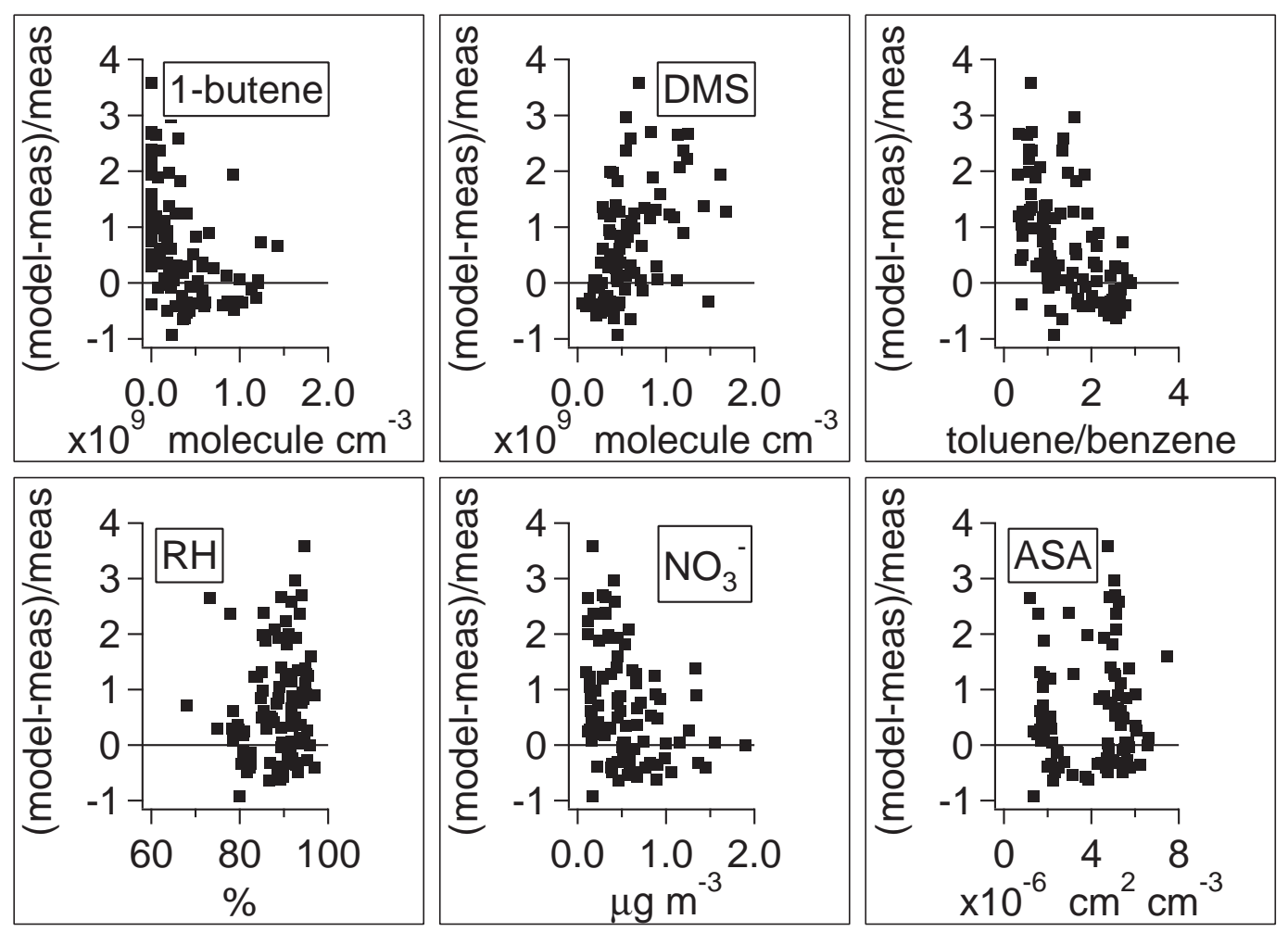

Fig. 9. $\mathrm{NO}_{3}$ model-measurements discrepancy as a function of selected physical and chemical parameters (ASA=Aerosol Surface Area). The aerosol $\mathrm{NO}_{3}^{-}$measurements are from the Aerosol Mass Spectrometer (Quinn et al., 2006).

purpose of this comparison is to assess how it compares to a more complete chemical model. There are two key differences between the MCM model and the steady-state calculations. First, the MCM includes several thousand species, whose concentration is calculated by the model from their measured precursors. About a thousand of these species react with $\mathrm{NO}_{3}$, but were not included in the pseudo first-order loss rate coefficient for $\mathrm{NO}_{3}\left(k_{\mathrm{NO}_{3}}\right.$ in Eq. 4$)$ because they were not measured. Second, the MCM model does not assume that $\mathrm{NO}_{3}$ is in steady-state (see Sect. 2 for details on the model integration), and therefore it is not susceptible to the breakdown of the steady-state approximation, particularly in the period just after sunset when the system requires an induction period for $\mathrm{NO}_{3}$ and $\mathrm{N}_{2} \mathrm{O}_{5}$ levels to reach their steadystate values. Figure 6 shows that the steady-state calculations were consistently higher than the MCM model, typically by a factor between 1.3 and 1.5.

The correlation between the steady-state calculation and the MCM model was good $\left(r^{2}=0.92\right.$, Fig. 3.2), indicating that the two calculations only disagreed on the absolute values of $\mathrm{NO}_{3}$ concentrations, likely related to missing terms in the steady-state expressions. The time to approach steady-state (calculated by a box model, Brown et al., 2003a; Aldener et al., 2006) for the average conditions of temperature, $\mathrm{NO}_{2}, \mathrm{O}_{3}$ and predicted sink rate coefficients of $\mathrm{NO}_{3}$ and $\mathrm{N}_{2} \mathrm{O}_{5}$ based on NMHCs and aerosol measurements, respectively, was less than one hour. Thus, although the steady state calculation may not have included all of the possible reactions of $\mathrm{NO}_{3}$ and may therefore have underestimated sinks, the approximation itself was likely valid for most of the night-time NEAQS 2004 data.

\subsection{Model-measurements discrepancy}

The discrepancy between the model and the measurements was investigated by plotting the (modelmeasurements)/measurements ratio vs. selected chemical and physical parameters. A selection of these plots for $\mathrm{NO}_{3}$ is shown in Fig. 9. The data were filtered to exclude day-time and the periods with fog; measurements lower than twice the detection limit were also omitted.

The model-measurements discrepancy showed a weak inverse correlation with the toluene/benzene ratio, a measure of the photochemical age of the air mass, suggesting that the agreement between the model and the measurements is better in photochemically young air masses or in freshly emitted plumes (Fig. 9). Such air masses tend to have higher $\mathrm{NO}_{\mathrm{x}}$ levels and thus faster production of $\mathrm{NO}_{3}$ radicals (Reaction R1). This is also consistent with the weak negative correlation with acetaldehyde (not shown in Fig. 9), a product of photochemical NMHCs oxidation. 
The most clearly identifiable trend was the positive correlation between the model-measurement discrepancy and DMS concentration (Fig. 9). The rate coefficient used in the model for the $\mathrm{NO}_{3}+\mathrm{DMS}$ reaction is consistent with the latest recommendation (Atkinson et al., 2003), which has an estimated uncertainty of $40 \%$. The positive correlation might therefore indicate an incomplete understanding of the DMS oxidation mechanism by $\mathrm{NO}_{3}$, particularly in the treatment of some of the night-time oxidation products. It must be noted that while the first steps of DMS oxidation are comparatively well known, there are still many uncertainties in the the distribution and the fate of the oxidation products (Barnes et al., 2006; Stark et al., 2007; Osthoff et al., 2009). The (model-measurements)/measurements ratio did not show a correlation with the concentrations of other primary NMHCs of anthropogenic (e.g. 1-butene) or biogenic (e.g. isoprene) origin (Fig. 9).

Besides gas-phase reactions, the most important removal pathway for the $\mathrm{NO}_{3}-\mathrm{N}_{2} \mathrm{O}_{5}$ system is the uptake on aerosol, which depends on two parameters, the aerosol surface area and the uptake coefficient, $\gamma_{\mathrm{N}_{2} \mathrm{O}_{5}}$ (Eq. 2). There was no correlation between the model-measurement discrepancy and the total aerosol surface area (Fig. 9).

The value of the uptake coefficient of $\mathrm{N}_{2} \mathrm{O}_{5}$ on sub-micron aerosol, which constituted most of the aerosol surface area during NEAQS 2004 (Quinn et al., 2006), is known to depend on the aerosol composition and RH, although there is some discrepancy in the literature regarding the RH dependence (e.g. Hu and Abbatt, 1997; Kane et al., 2001; Hallquist et al., 2003; Thornton et al., 2003; Badger et al., 2006; Davis et al., 2008). However, in this work there was no clear relationship between the model-measurements discrepancy and relative humidity or aerosol composition, aside from a weak negative correlation with $\mathrm{NO}_{3}^{-}$(Fig. 9). Although this correlation could indicate reduced $\mathrm{N}_{2} \mathrm{O}_{5}$ uptake at higher nitrate concentrations in aerosol (Mentel et al., 1999; Hallquist et al., 2003), it is difficult to interpret and is possibly correlated with other variables, such as the photochemical age of the air mass. Thus, the model-measurement comparison could not identify an obvious trend that could be related to the variability in the rate of $\mathrm{N}_{2} \mathrm{O}_{5}$ heterogeneous hydrolysis.

The sensitivity of the model results to the uptake coefficients of $\mathrm{NO}_{3}$ and $\mathrm{N}_{2} \mathrm{O}_{5}$ will be discussed in more detail in the following section (Sect. 5).

\section{Model sensitivity to selected $\mathrm{NO}_{3}$ and $\mathrm{N}_{2} \mathrm{O}_{5}$ sinks}

This section examines several key uncertainties in the loss processes for $\mathrm{NO}_{3}$ and $\mathrm{N}_{2} \mathrm{O}_{5}$, including the homogeneous and heterogeneous hydrolysis of $\mathrm{N}_{2} \mathrm{O}_{5}$, the heterogeneous uptake of $\mathrm{NO}_{3}$ on aerosol, the dry deposition of $\mathrm{NO}_{3}$ and $\mathrm{N}_{2} \mathrm{O}_{5}$ to the ocean surface. The response of the model to these uncertainties was investigated by changing the model parameters and comparing the results with the "base" model.

\section{$5.1 \mathrm{~N}_{2} \mathrm{O}_{5}$ homogeneous and heterogeneous hydrolysis}

Several laboratory experiments (see Atkinson et al., 2003, and references therein) have suggested that homogeneous gas-phase hydrolysis of $\mathrm{N}_{2} \mathrm{O}_{5}$ to $\mathrm{HNO}_{3}$ has a rate coefficient sufficient to make the process important in the atmosphere. The rate coefficient is small, but the reaction is parameterized as the sum of a first $\left(k_{\left[\mathrm{H}_{2} \mathrm{O}\right]}=2.5 \times 10^{-22} \mathrm{~cm}^{3}\right.$ molecule $\left.\mathrm{e}^{-1} \mathrm{~s}^{-1}\right)$ and second $\left(k_{\left[\mathrm{H}_{2} \mathrm{O}\right]^{2}}=1.8 \times 10^{-39} \mathrm{~cm}^{3}\right.$ molecule $\left.{ }^{-1} \mathrm{~s}^{-1}\right)$ order process in $\mathrm{H}_{2} \mathrm{O}$, whose ambient concentration is large, so the effective pseudo first-order rate coefficient is significant (Mentel et al., 1996; Wahner et al., 1998). Homogenous hydrolysis is included in the IUPAC Gas Kinetics Data Evaluation (Atkinson et al., 2003) and, as such, was part of the "base" model. Some previous studies (Aldener et al., 2006; Brown et al., 2006) have suggested that the kinetics of the homogeneous hydrolysis is inconsistent with field data, while others (e.g. Ambrose et al., 2007) have shown better agreement between measurements and calculations if homogeneous hydrolysis was included.

Except for the periods of the R/V Brown cruise with fog, uptake on sub-micron aerosol was always the most important loss processes of $\mathrm{N}_{2} \mathrm{O}_{5}$, with a loss rate between $1 \times 10^{5}$ and $5 \times 10^{6}$ molecule $\mathrm{cm}^{-3} \mathrm{~s}^{-1}$. The reaction rate of $\mathrm{N}_{2} \mathrm{O}_{5}$ homogeneous hydrolysis was, on average, about half that of the aerosol uptake, with the second order $\left(\right.$ in $\mathrm{H}_{2} \mathrm{O}$ ) component about 3-4 times larger than the first order component. Because it is impossible to distinguish between homogeneous and heterogeneous processes in the comparison between the measurements and the model, the impact of this process is assessed here only by comparisons between model runs using different parametrizations for each reaction. The results are illustrated in Fig. 10, which compares the test models with the "base" model.

When $k_{\left[\mathrm{H}_{2} \mathrm{O}\right]^{2}}$ was set to zero, modelled [ $\left.\mathrm{N}_{2} \mathrm{O}_{5}\right]$ increased by $27 \%$ (not shown in Fig. 10) and when both $k_{\left[\mathrm{H}_{2} \mathrm{O}\right]}$ and $k_{\left[\mathrm{H}_{2} \mathrm{O}\right]^{2}}$ were set to zero, modelled $\left[\mathrm{N}_{2} \mathrm{O}_{5}\right]$ increased by $38 \%$, on average (Fig. 10a). In the presence of homogeneous hydrolysis, the model was less sensitive to changes in $\gamma_{\mathrm{N}_{2} \mathrm{O}_{5}}$. Increasing $\gamma \mathrm{N}_{2} \mathrm{O}_{5}$ from the "base" value of 0.03 (Aldener et al., 2006) to 0.06 (Kane et al., 2001) and decreasing it to 0.004 (Badger et al., 2006), caused modelled $\left[\mathrm{N}_{2} \mathrm{O}_{5}\right]$ to decrease by $31 \%$ and increase by $66 \%$, respectively (Fig. 10b and c).

Since the "base" model, which included $\mathrm{N}_{2} \mathrm{O}_{5}$ homogeneous hydrolysis, generally overestimated the measurements, a value of $\gamma_{\mathrm{N}_{2} \mathrm{O}_{5}}<0.03$ would increase the average discrepancy with the measurements (on the occasions when the model underestimated the measurements, a value of $\gamma_{\mathrm{N}_{2} \mathrm{O}_{5}} \simeq 0.004$ could result in a better agreement with the measurements). On the other hand, neglecting $\mathrm{N}_{2} \mathrm{O}_{5}$ homogeneous hydrolysis would cause a much larger overestimation of the measurements, unless it was compensated by a faster uptake on sub-micron aerosol, inconsistent with the 

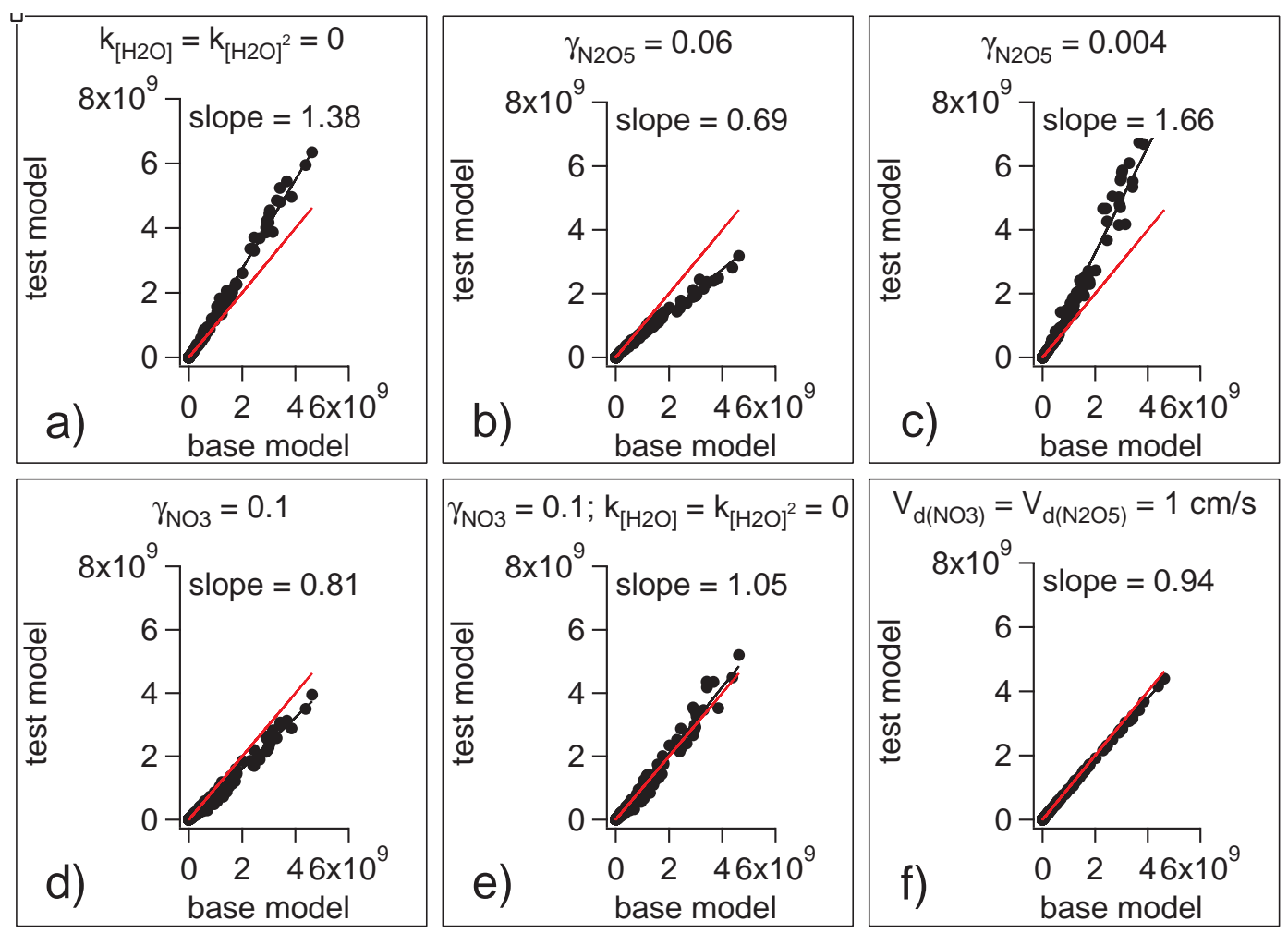

Fig. 10. Test models vs. "base" model $\left(\left[\mathrm{N}_{2} \mathrm{O}_{5}\right]\right.$ in molecule $\left.\mathrm{cm}^{-3}\right)$. The black line is the fit and the red line is $1: 1$.

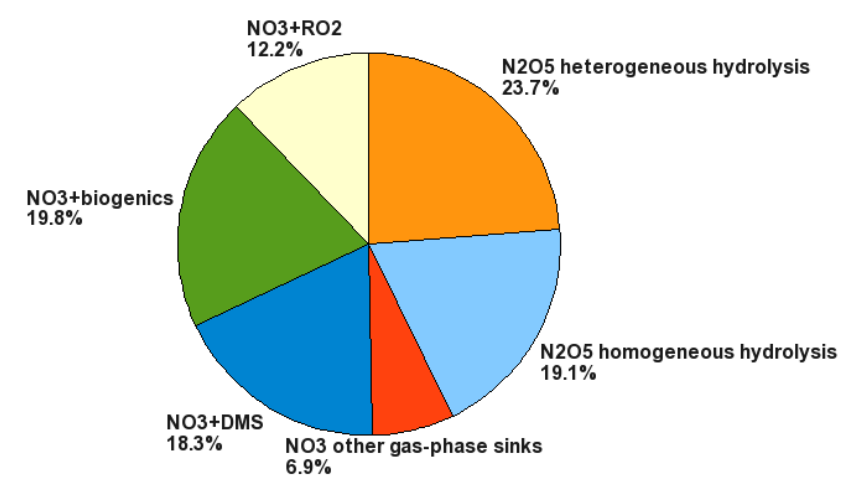

Fig. 11. Campaign averaged percent contributions to the total $\mathrm{NO}_{3} / \mathrm{N}_{2} \mathrm{O}_{5}$ loss rate during the $\mathrm{R} / \mathrm{V}$ Brown cruise.

laboratory studies which all suggest that $\gamma_{\mathrm{N}_{2} \mathrm{O}_{5}}<0.06$ (see Thornton et al., 2003; Folkers et al., 2003; Anttila et al., 2006; Badger et al., 2006; McNeill et al., 2006; Park et al., 2007; Davis et al., 2008, and references therein).

The model response to variations in the value of $\gamma \mathrm{N}_{2} \mathrm{O}_{5}$ suggests that this parameter was not responsible for the model-measurements discrepancy (see also Sect. 4.2) and that, under the conditions encountered during NEAQS 2004, the value of $\gamma_{\mathrm{N}_{2} \mathrm{O}_{5}}$ was, on average, $>1 \times 10^{-2}$. Values of $\gamma \mathrm{N}_{2} \mathrm{O}_{5}$ of the order of $10^{-3}$ could in general be excluded, particularly if $\mathrm{N}_{2} \mathrm{O}_{5}$ homogeneous hydrolysis were to be neglected.

These conclusions are in broad accord with previous surface studies in marine environments, all of which found rapid losses of $\mathrm{N}_{2} \mathrm{O}_{5}$ and identified an important role for $\mathrm{N}_{2} \mathrm{O}_{5}$ hydrolysis in the budgets of $\mathrm{NO}_{3}$ and $\mathrm{N}_{2} \mathrm{O}_{5}$ (e.g. Allan et al., 1999, 2000; Brown et al., 2004; Vrekoussis et al., 2004; Aldener et al., 2006; Ambrose et al., 2007). It must be noted, however, that the limited database of measurements taken above the nocturnal and/or marine boundary layers have shown greater variability in the $\mathrm{N}_{2} \mathrm{O}_{5}$ loss processes and longer lifetimes for $\mathrm{NO}_{3}$ and $\mathrm{N}_{2} \mathrm{O}_{5}$ at higher altitudes (Allan et al., 2002; Stutz et al., 2004; Brown et al., 2006, 2007a,b).

\section{$5.2 \mathrm{NO}_{3}$ heterogeneous uptake, $\mathrm{NO}_{3}$ and $\mathrm{N}_{2} \mathrm{O}_{5}$ dry deposition}

The model was much less sensitive to the heterogeneous uptake of $\mathrm{NO}_{3}$. The value of $\gamma_{\mathrm{NO}_{3}}$ was increased by a factor of 50 from the "base" value of 0.002 (Thomas et al., 1998) to 0.1 (Mak et al., 2007) to cover a range of possible values. This led to a decrease in modelled $\left[\mathrm{N}_{2} \mathrm{O}_{5}\right]$ by only $20 \%$ in the presence (Fig. 10d) and a slight increase (5\%) in the absence (Fig. 10e) of homogeneous hydrolysis. Therefore, even though the uptake coefficient for $\mathrm{NO}_{3}$ may be poorly 


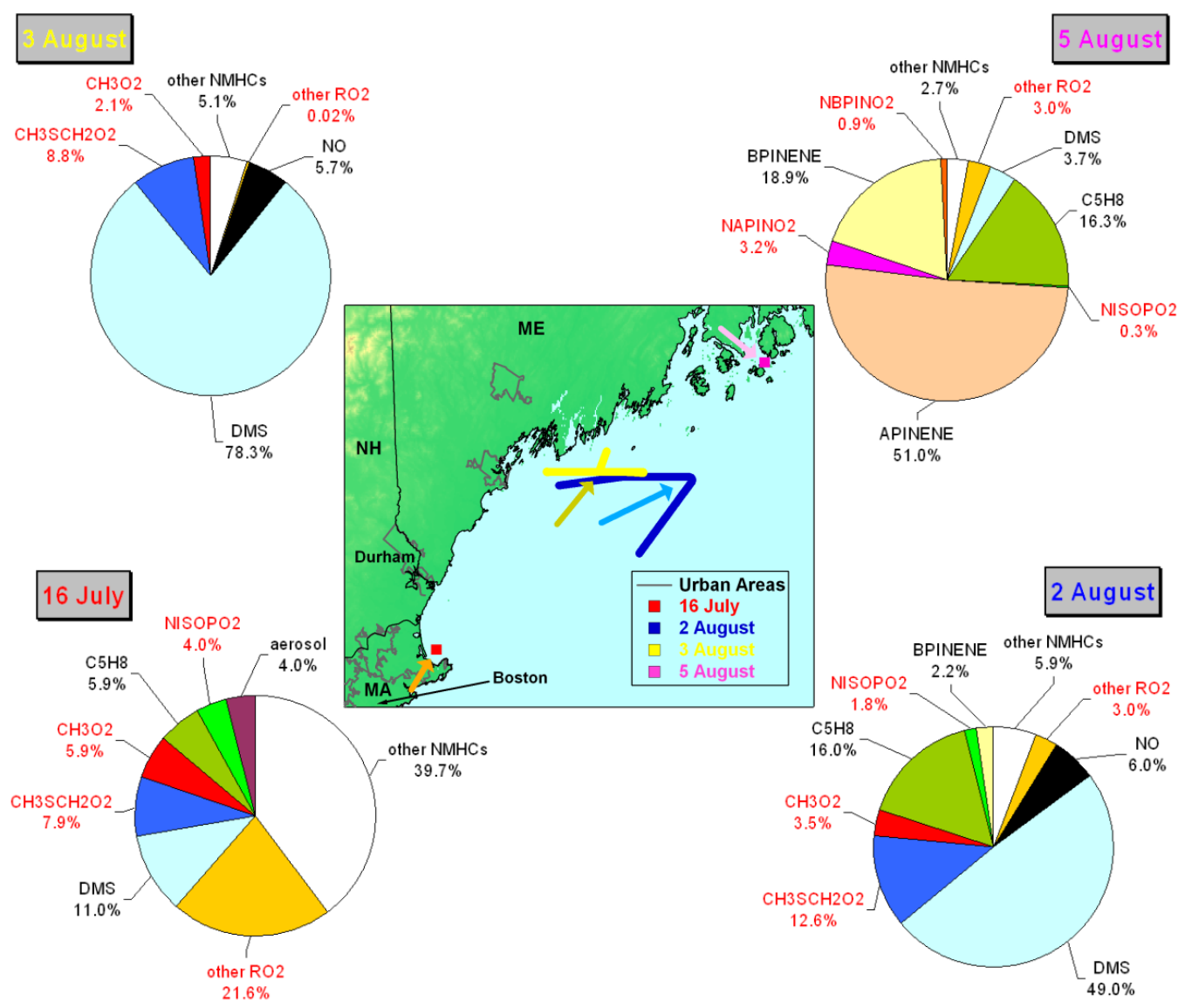

Fig. 12. Position and track of the R/V Brown with average local wind direction during four nights of the NEAQS 2004 campaign (16 July, 2 , 3 and 5 August). The pie charts show the average (03:00-06:00 a.m. GMT) percent contribution to $\mathrm{NO}_{3}$ direct loss rate of different species during the four nights. The peroxy radicals contributions are highlighted in red.

characterized from the available laboratory data, it did not, at least in this study, have a large impact on the loss rates of $\mathrm{NO}_{3}$ and $\mathrm{N}_{2} \mathrm{O}_{5}$. Under conditions with weak $\mathrm{N}_{2} \mathrm{O}_{5}$ losses, however, the importance of the heterogeneous uptake of $\mathrm{NO}_{3}$ might be larger.

In the "base" model $\mathrm{NO}_{3}$ and $\mathrm{N}_{2} \mathrm{O}_{5}$ did not undergo dry deposition. In a test model, both $V_{d\left(\mathrm{NO}_{3}\right)}$ and $V_{d\left(\mathrm{~N}_{2} \mathrm{O}_{5}\right)}$ were set to $1.0 \mathrm{~cm} \mathrm{~s}^{-1}$, similar to the deposition velocity of $\mathrm{HNO}_{3}$ found by Brown et al. (2004) in a shallow marine boundary layer. This resulted in a decrease of the calculated concentrations of $\mathrm{N}_{2} \mathrm{O}_{5}$ by only $6 \%$ (Fig. 10f), suggesting that this process was not very significant under the NEAQS 2004 conditions. Deposition to the surface of $\mathrm{NO}_{3}$ and $\mathrm{N}_{2} \mathrm{O}_{5}$ was calculated using a constant boundary layer height of $100 \mathrm{~m}$. While this is a reasonable approximation and consistent with the sonde data for most of the R/V Brown cruise (i.e. when the R/V Brown was in the open sea), it was not necessarily true when the ship was closer to the coast, where the boundary layer height could be more variable and more shallow layers might be present (Angevine et al., 2006). In those cases, deposition to the surface of $\mathrm{NO}_{3}$ and $\mathrm{N}_{2} \mathrm{O}_{5}$ might have played a more important role.

\section{$6 \mathrm{NO}_{3}$ chemistry and peroxy radical interactions}

The explicit chemistry of the MCM allowed for a detailed analysis of the gas-phase losses of $\mathrm{NO}_{3}$, with particular focus on the reactivity between $\mathrm{NO}_{3}$ and organic peroxy radicals $\left(\mathrm{RO}_{2}\right)$, a significant uncertainty in the fate of $\mathrm{NO}_{3}$. Using the results from the "base" model, the relative importance of the reactions that contributed to the destruction of $\mathrm{NO}_{3}$ was analyzed in terms of the chemical composition of the sampled air masses. On average, during the entire cruise of the $\mathrm{R} / \mathrm{V}$ Brown, $\mathrm{N}_{2} \mathrm{O}_{5}$ removal by heterogenous or homogeneous hydrolysis accounted respectively for $\sim 24 \%$ and $\sim 19 \%$ of the total loss rate of the $\mathrm{NO}_{3}-\mathrm{N}_{2} \mathrm{O}_{5}$ system in the "base" model (Fig. 11). The following analysis will be restricted to 
direct loss of $\mathrm{NO}_{3}$ only -i.e., not considering the indirect loss of this radical via hydrolysis of $\mathrm{N}_{2} \mathrm{O}_{5}$. About $57 \%$ of the total loss rate of the $\mathrm{NO}_{3}-\mathrm{N}_{2} \mathrm{O}_{5}$ system was due to gas-phase reactions of $\mathrm{NO}_{3}$, mostly with DMS and biogenic NMHCs (isoprene, $\alpha$-pinene and $\beta$-pinene). Aldener et al. (2006) derived similar contributions from their observations in the same region during NEAQS 2002, except for the significant role $\left(\sim 12 \%\right.$, Fig. 11) played by the reactions of $\mathrm{NO}_{3}$ with the organic peroxy radicals.

Four nights (16 July and 2, 3, 5 August) were selected to investigate $\mathrm{NO}_{3}$ gas-phase reactivity in air masses of different chemical composition. Fog was absent during all of these nights. These case studies illustrate examples when nighttime chemistry was controlled by anthropogenic hydrocarbons (16 July), by a mixture of marine and biogenic emissions (2 August), by DMS (3 August) and by terrestrially emitted biogenic hydrocarbons (5 August). In the following discussion, times will be indicated in GMT (four hours later than local time) and some species will be indicated with the MCM codename rather than the chemical formula, for simplicity. A table with the corresponding structure can be found in the Appendix A.

\subsection{July - anthropogenic NMHCs}

During the night of 16 July the R/V Brown was off Cape Ann (MA), about $50 \mathrm{~km}$ Northeast of Boston (Fig. 12). The local wind direction was predominantly from the Southwest, i.e. the Boston area. During the first part of the night (before 06:00 a.m.) a mixture of isoprene, DMS and hydrocarbons of mostly anthropogenic origin (such as styrene and 2-methyl1-butene) controlled the concentration of $\mathrm{NO}_{3}$. While DMS was entrained into air masses transported over water, isoprene and the anthropogenic NMHCs were likely transported from the northern Boston area, which was less than $3 \mathrm{~h}$ upwind at the average local wind speed of $5 \mathrm{~m} \mathrm{~s}^{-1}$ (Fig. 12). The isoprene mixing ratio was almost $0.5 \mathrm{ppb}$ before sunset and decreased rapidly throughout the night.

The modelled concentrations of $\mathrm{RO}_{2}$ show that at the beginning of the night the nitro-peroxy radical formed by the reaction between isoprene and $\mathrm{NO}_{3}$ (NISOPO2) was the major component of the $\mathrm{RO}_{2}$ pool, accounting for about one third of the total $\mathrm{RO}_{2}$ concentration and twice as abundant as $\mathrm{CH}_{3} \mathrm{O}_{2}$ and $\mathrm{CH}_{3} \mathrm{SCH}_{2} \mathrm{O}_{2}$ (Fig. 13). However, NISOPO2 concentration decreased quickly and accounted for only a small fraction of the organic peroxy radical concentration $(<10 \%)$ after 03:00 a.m.. By contrast, the peroxy radicals formed from the oxidation of anthropogenic NMHCs showed an increase after 03:00 a.m., related to measured increases of anthropogenic NMHCs, likely transported from the Boston urban area (Fig. 12). After 06:00 a.m. an influx of NO, possibly from local sources, caused the suppression of $\mathrm{RO}_{2}$ (Fig. 13) and the destruction of $\mathrm{NO}_{3}$, by $\mathrm{NO}_{3}+\mathrm{NO}(>90 \%$ of the direct $\mathrm{NO}_{3}$ destruction rate).
The average (03:00-06:00 a.m.) contribution to $\mathrm{NO}_{3}$ loss rate is shown in percent in Fig. 12. In addition to isoprene and DMS, a consistent fraction of the $\mathrm{NO}_{3}$ loss $(\sim 40 \%)$ was due to reactions with a large number of NMHCs, mostly of anthropogenic origin, each accounting for $5 \%$ or less of the direct $\mathrm{NO}_{3}$ loss rate. Peroxy radicals accounted for a large fraction (approximately 40\%) of the average direct $\mathrm{NO}_{3}$ removal rate (Fig. 12). The most important contributors were $\mathrm{CH}_{3} \mathrm{O}_{2}$ and $\mathrm{CH}_{3} \mathrm{SCH}_{2} \mathrm{O}_{2}\left(\sim 6 \%\right.$ and $\sim 8 \%$ of the direct $\mathrm{NO}_{3}$ loss, respectively), followed by the peroxy radicals derived from isoprene and anthropogenic NMHCs oxidation.

\subsection{2 and 3 August: DMS}

During the nights of 2 and 3 August, the R/V Brown was in the Gulf of Maine, more than $50 \mathrm{~km}$ from the coast. The local wind direction was from the Southwest on 2 August and from the South-Southwest on 3 August (Fig. 12). On both nights, the sampled air masses were rich in DMS, related to the relatively long transport over the sea. On 2 August, high concentrations of biogenic hydrocarbons (mostly isoprene: $\sim 70$ ppt, on average, between 03:00 and 06:00 a.m.) emitted from the Maine forests were also measured.

The modelled concentrations of $\mathrm{RO}_{2}$ showed that on both nights the most abundant peroxy radicals were $\mathrm{CH}_{3} \mathrm{O}_{2}$ and $\mathrm{CH}_{3} \mathrm{SCH}_{2} \mathrm{O}_{2}$, which together accounted for almost the entire $\mathrm{RO}_{2}$ pool (Fig. 6.3 and 13). The peroxy radical NISOPO2, derived from the nocturnal oxidation of isoprene, contributed less than $10 \%$ to the total $\mathrm{RO}_{2}$ concentration on the night of 2 August.

On 2 August, the main losses for $\mathrm{NO}_{3}$ were DMS, isoprene and $\beta$-pinene (Fig. 12). The largest loss was the reaction with DMS, which accounted for almost half of the direct $\mathrm{NO}_{3}$ loss rate. The related peroxy radicals, the most important of which was $\mathrm{CH}_{3} \mathrm{SCH}_{2} \mathrm{O}_{2}$ (Fig. 12), accounted overall for $\sim 13 \%$ of the direct $\mathrm{NO}_{3}$ loss rate. This night showed that under certain conditions the reaction of $\mathrm{NO}_{3}$ with some peroxy radicals, such as $\mathrm{CH}_{3} \mathrm{SCH}_{2} \mathrm{O}_{2}$, can be nearly as rapid as the reaction with reactive NMHCs, such as isoprene.

On 3 August $\mathrm{NO}_{3}$ was consumed almost entirely by the reaction with DMS and with the peroxy radical derived from DMS $+\mathrm{NO}_{3}\left(\mathrm{CH}_{3} \mathrm{SCH}_{2} \mathrm{O}_{2}\right.$, Fig. 12). $\mathrm{CH}_{3} \mathrm{SCH}_{2} \mathrm{O}_{2}$ was the most important organic peroxy radical, followed by $\mathrm{CH}_{3} \mathrm{O}_{2}$ (Fig. 13). The two species accounted for $\sim 9 \%$ and $\sim 2 \%$ of the direct $\mathrm{NO}_{3}$ removal rate, respectively. $\mathrm{CH}_{3} \mathrm{O}_{2}$ was also a product of DMS oxidation, via the decomposition of the $\mathrm{CH}_{3} \dot{\mathrm{SO}}_{2}$ radical (see Sect. 3.2).

\subsection{August: biogenic NMHCs}

During the night of 5 August, the R/V Brown was off the coast of Maine, South of the Acadia National Park (Fig. 12). The sampled air masses were from the Northwest, according to the local wind direction, and were characterized by large concentrations of biogenic hydrocarbons emitted from 
forested areas near the coast. The measured concentrations of isoprene, $\alpha$-pinene and $\beta$-pinene increased during the first part of the night until approximately 06:00-07:00 a.m., then decreased as the ship moved away from the coast. Between 03:00 and 06:00 a.m., the average concentrations of isoprene, $\alpha$-pinene and $\beta$-pinene were 360, 120 and $110 \mathrm{ppt}$, respectively. These high levels of biogenic compounds led to rapid $\mathrm{NO}_{3}$ removal, as has been shown in a previous study in the same area (Warneke et al., 2004; Aldener et al., 2006).

The modelled concentrations of organic peroxy radicals (Fig. 13) show that the $\mathrm{RO}_{2}$ pool consisted mainly of peroxy radicals from the reaction of $\mathrm{NO}_{3}$ with $\beta$-pinene (NBPINO2), $\alpha$-pinene (NAPINO2) and isoprene (NISOPO2). The most important was NAPINO2 which accounted for about $40-50 \%$ of total $\mathrm{RO}_{2}$. Concentrations of peroxy radicals increased through the night, peaking around 07:00 a.m., following variations in the concentrations of their precursors.

Figure 12 shows that isoprene, $\alpha$-pinene and $\beta$-pinene accounted for the majority of the $\mathrm{NO}_{3}$ destruction rate $(\sim 86 \%)$. The peroxy radicals derived from the reactions of these hydrocarbons with $\mathrm{NO}_{3}$, together, accounted for $4-5 \%$ of the direct $\mathrm{NO}_{3}$ loss.

The measured concentrations of $\alpha$-pinene and $\beta$-pinene were very similar, but the relative importance of $\alpha$-pinene as an $\mathrm{NO}_{3}$ loss was much larger than that of $\beta$-pinene and also of that of isoprene, which was present at concentrations more than twice as large. The contribution of $\alpha$-pinene to the $\mathrm{RO}_{2}$ pool was also larger than the contributions of $\beta$-pinene and isoprene (Fig. 13). This was due to the rapid rate coefficient of $\alpha$-pinene $+\mathrm{NO}_{3}$ which is about 2.5 and 9 times larger than those of $\beta$-pinene $+\mathrm{NO}_{3}$ and isoprene $+\mathrm{NO}_{3}$, respectively (Atkinson and Arey, 2003).

\subsection{Peroxy radicals as $\mathrm{NO}_{3}$ sinks}

The reaction rate analysis discussed in the previous sections highlighted the role of peroxy radicals as $\mathrm{NO}_{3}$ losses. The interactions between organic peroxy radicals and $\mathrm{NO}_{3}$ have been studied previously during several field campaigns (e.g. Mihelcic et al., 1993; Cantrell et al., 1997; Carslaw et al., 1997; Bey et al., 2001; Geyer et al., 2003; Platt et al., 2002; Salisbury et al., 2001), although most of these studies were concerned with the source of night-time peroxy radicals (i.e. from $\mathrm{NO}_{3}$ vs. $\mathrm{O}_{3}$ reactions with $\mathrm{NMHCs}$ ) rather then with the role of $\mathrm{RO}_{2}$ in the destruction of the nitrate radical. On three of the four nights analyzed in detail in this work (Fig. 12), the reaction between $\mathrm{NO}_{3}$ and $\mathrm{CH}_{3} \mathrm{O}_{2}$ accounted for $2-6 \%$ of the direct loss rate of $\mathrm{NO}_{3}$, while other peroxy radicals, like $\mathrm{CH}_{3} \mathrm{SCH}_{2} \mathrm{O}_{2}$, accounted for even a larger fraction of $\mathrm{NO}_{3}$ destruction (8-13\%). Depending on the chemical composition of the air mass, other peroxy radicals (e.g. of biogenic or anthropogenic origin) were significant $\mathrm{NO}_{3}$ sinks and, taken together, they could account for a large fraction of the $\mathrm{NO}_{3}$ direct loss rate (e.g. on 16 July, Fig. 12).
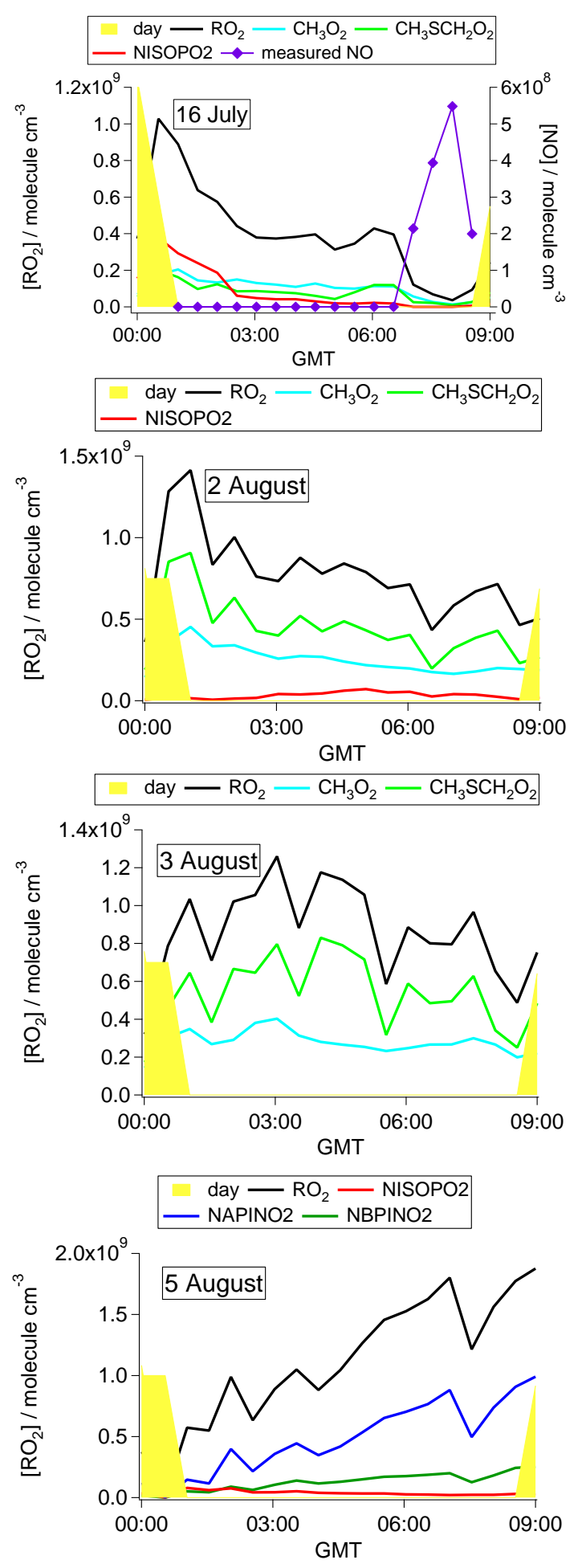

Fig. 13. Modelled organic peroxy radicals $\left(\mathrm{RO}_{2}\right)$ during four nights of the R/V Brown cruise (16 July, 2, 3 and 5 August). 


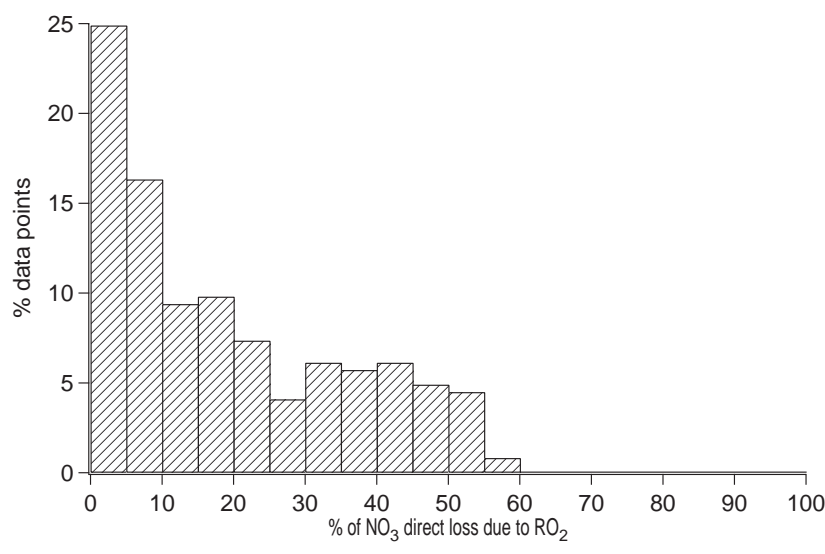

Fig. 14. Frequency distribution of the percent direct loss of $\mathrm{NO}_{3}$ due to reaction with peroxy radicals during the $\mathrm{R} / \mathrm{V}$ Brown cruise (days with fog excluded).

The actual impact of peroxy radicals as $\mathrm{NO}_{3}$ sinks depends on a number of factors including the presence of local $\mathrm{NO}$ sources (only a few ppt of $\mathrm{NO}$ will make $\mathrm{NO}_{3}+\mathrm{NO}$ competitive with $\mathrm{NO}_{3}+\mathrm{RO}_{2}$ ) and the reactivity of the primary NMHCs. According to the MCM model calculations, the reactions with other secondary products of NMHCs oxidation with $\mathrm{NO}_{3}$ was less important, at least under the conditions encountered during NEAQS 2004. In air masses rich in highly reactive hydrocarbons, such as monoterpenes, the reaction with the hydrocarbons dominated over the reactivity with their correspondent $\mathrm{RO}_{2}$ (e.g. on 5 August, Fig. 12).

The role of peroxy radicals as $\mathrm{NO}_{3}$ sinks is illustrated in Fig. 14. The percent of the direct loss of $\mathrm{NO}_{3}$ attributable to the reactions with $\mathrm{RO}_{2}$ varied depending on the conditions, but the average and median contributions were $19 \%$ and $15 \%$, respectively. Although large removal rates of $\mathrm{NO}_{3}$ due to $\mathrm{RO}_{2}$ reaction were rare (the 75th percentile in the distribution occurred at a $32 \%$ contribution to direct $\mathrm{NO}_{3}$ loss), the comparatively high median contribution suggests that this process can be important. In only $25 \%$ of the data was the direct loss of $\mathrm{NO}_{3}$ to $\mathrm{RO}_{2}$ smaller than $5 \%$.

There are several consequences to direct loss of $\mathrm{NO}_{3}$ via reaction with $\mathrm{RO}_{2}$. Firstly, Aldener et al. (2006) speculated, in their study of the NEAQS 2002 campaign, that the discrepancies between the steady-state calculations and the measurements could be attributed to secondary chemistry between $\mathrm{NO}_{3}$ and second generation reaction products. The analysis discussed here suggests that the peroxy radicals can account, at least in part, for the $\mathrm{NO}_{3}$ losses missing from the steady-state calculations. Including these reactions in the steady-state analysis of field data could help to close the budget of $\mathrm{NO}_{3}$.

Secondly, the reactions between peroxy radicals and $\mathrm{NO}_{3}$ can form $\mathrm{OH}$, via the formation of alkoxy radicals and of $\mathrm{HO}_{2}$ (Vaughan et al., 2006), thus contributing to the oxida- tion of NMHCs at night. The total calculated formation rate of $\mathrm{OH}$ during the nights of the NEAQS 2004 cruise was on the order of $0.5-2.5 \times 10^{5}$ molecule ${ }^{-1} \mathrm{~cm}^{3} \mathrm{~s}^{-1}$. The formation pathways were variable, depending on the chemical conditions encountered. In air masses rich in biogenic NMHCs (e.g. on 5 August), the most important source of night-time $\mathrm{OH}$ was the ozonolysis of the monoterpenes. On most of the other nights analyzed here, the formation of $\mathrm{OH}$ was dominated by the reactions of $\mathrm{HO}_{2}$ with $\mathrm{O}_{3}$ and with $\mathrm{NO}_{3}$. Alkoxy radicals (RO), formed by the reactions of $\mathrm{RO}_{2}$ with $\mathrm{NO}_{3}$, contributed to the formation of night-time $\mathrm{OH}$, mainly via their reactions with $\mathrm{O}_{2}$ to form $\mathrm{HO}_{2}$. In the case of the $\mathrm{CH}_{3} \mathrm{SCH}_{2} \mathrm{O}_{2}$ radical, the dominant pathway to form nighttime $\mathrm{OH}$ was via the formation of the methylsulphonyl radical, followed by decomposition to $\mathrm{CH}_{3} \mathrm{O}_{2}$ (Sect. 3.2).

Finally, the $\mathrm{RO}_{2}+\mathrm{NO}_{3}$ reactions decrease the removal of $\mathrm{NO}_{\mathrm{x}}$ during the night. This process occurs via conversion of $\mathrm{NO}_{2}$ to $\mathrm{NO}_{3}$ (Reaction R1), followed by reaction with NMHCs to form $\mathrm{HNO}_{3}$, which is typically lost to deposition. However, if a substantial fraction of $\mathrm{NO}_{3}$ reforms $\mathrm{NO}_{2}$ by reacting with a variety of peroxy radicals the efficiency of the night-time $\mathrm{NO}_{\mathrm{x}}$ removal process is reduced. This would result in more $\mathrm{NO}_{2}$ available for photolysis at sunrise, with significant impact on the formation of $\mathrm{O}_{3}$. Therefore, if the role of peroxy radicals in the direct loss of $\mathrm{NO}_{3}$ is as large as $20 \%$, these reactions could have a significant impact on the oxidative budget of the troposphere.

There are two major uncertainties in this analysis. One is in the kinetic parameters used in the Master Chemical Mechanism. The reaction mechanism and the rate coefficients of selected peroxy radicals (such as $\mathrm{CH}_{3} \mathrm{O}_{2}, \mathrm{C}_{2} \mathrm{H}_{5} \mathrm{O}_{2}$, $\left.\mathrm{C}_{5} \mathrm{H}_{9} \mathrm{O}_{2}, \mathrm{C}_{6} \mathrm{H}_{1} 1 \mathrm{O}_{2}, \mathrm{CH}_{3} \mathrm{C}(\mathrm{O}) \mathrm{O}_{2}\right)$ with $\mathrm{NO}_{3}$ have been measured in the laboratory (Platt et al., 1990; Canosa-Mas et al., 1996; Vaughan et al., 2006). However, the MCM contains nearly one thousand organic peroxy radicals and, for the large majority of these, there are no kinetic data available. Therefore, according to the MCM protocol (Jenkin et al., 1997; Saunders et al., 2003), the same rate coefficient of $\mathrm{C}_{2} \mathrm{H}_{5} \mathrm{O}_{2}\left(2.5 \times 10^{-12} \mathrm{~cm}^{3}\right.$ molecule $\left.{ }^{-1} \mathrm{~s}^{-1}\right)$ is used for nonacyl $\mathrm{RO}_{2}$ and the same rate coefficient of $\mathrm{CH}_{3} \mathrm{C}(\mathrm{O}) \mathrm{O}_{2}$ $\left(4.1 \times 10^{-12} \mathrm{~cm}^{3}\right.$ molecule $\left.{ }^{-1} \mathrm{~s}^{-1}\right)$ is used for acyl $\mathrm{RO}_{2}$. The rate coefficient for the $\mathrm{CH}_{3} \mathrm{SCH}_{2} \mathrm{O}_{2}+\mathrm{NO}_{3}$ reaction was estimated at $2.0 \times 10^{-12} \mathrm{~cm}^{3}$ molecule ${ }^{-1} \mathrm{~s}^{-1}$ based on similarity with the alkyl peroxy radicals. While these estimates are in accord with the present understanding of the chemistry, additional laboratory experiments, particularly for sulphurcontaining $\mathrm{RO}_{2}$ would improve the accuracy of the calculations and help to assess more precisely the role of peroxy radicals as $\mathrm{NO}_{3}$ sinks.

The other uncertainty is in the modelled concentration and speciation of $\mathrm{RO}_{2}$. Since there were no measurements of peroxy radicals during the R/V Brown cruise, the reliability of the model in predicting peroxy radicals concentrations can only be estimated on the basis of previous modelmeasurements comparisons. Several studies have compared 
measurements by PERCA (Peroxy Radical Chemical Amplifier, which measures $\mathrm{HO}_{2}+\mathrm{RO}_{2}$ ) with the calculations of models based upon the MCM (Carslaw et al., 1997, 1999, 2002; Platt et al., 2002; Geyer et al., 2003; Emmerson et al., 2007; Fleming et al., 2006; Sommariva et al., 2007). In most of these previous studies, the agreement between the model and the measurements was typically better than $30 \%$. The models tended to overestimate $\mathrm{HO}_{2}$ (as measured by LIF) during the day, suggesting that $\mathrm{RO}_{2}$ might be underestimated. However, the agreement between modelled and measured $\mathrm{HO}_{2}$ was within 30-40\% during the night (Sommariva et al., 2007) giving more confidence in the model results of $\mathrm{RO}_{2}$ at night-time. Therefore, in the absence of peroxy radicals measurements with which the MCM model could be compared, it can reasonably be assumed that the model performance was at least similar to the previous models (i.e. within $30 \%$ of the actual concentration).

Assessing the reliability of the modelled speciation of the $\mathrm{RO}_{2}$ pool is more difficult, because it depends on the treatment of peroxy radicals in the MCM, especially at low $\left[\mathrm{NO}_{\mathrm{x}}\right]$, and on the estimates introduced for the missing kinetic data (Jenkin et al., 1997; Saunders et al., 2003). To our knowledge, there is no experimental information available that could help to determine how well an MCM-based model could reproduce the actual concentrations of the individual organic peroxy radicals.

\section{Conclusions}

During the NEAQS 2004 campaign the NOAA research vessel R/V Brown cruised off the coast of New England measuring, among other chemical and physical parameters, radical species and their precursors. A model was used to study the chemical processes in this marine environment under different conditions, with a particular focus on night-time chemistry. The model was based upon the Master Chemical Mechanism (MCM) and constrained to the measurements taken onboard the ship.

The model was used to calculate $\mathrm{OH}$ concentrations for the entire cruise of the R/V Brown in order to provide a reliable estimate of $[\mathrm{OH}]$ for the analysis of the field data (e.g. Osthoff et al., 2006, 2009). OH calculated by the model was compared to a parametrization (Ehhalt and Rohrer, 2000) previously used in tropospheric chemistry studies, which was found to likely overestimate $[\mathrm{OH}]$ on average by 20 $40 \%$, under the conditions encountered during the cruise. The model also calculated the concentrations of inorganic $\left(\mathrm{HO}_{2}\right)$ and organic $\left(\mathrm{RO}_{2}\right)$ peroxy radicals and determined the composition of the peroxy radical pool during the entire R/V Brown cruise.
$\mathrm{NO}_{3}$ and $\mathrm{N}_{2} \mathrm{O}_{5}$ concentrations were calculated by the model for comparison with measurements made by Cavity Ring-Down Spectroscopy (CaRDS). The model overestimated the measurements by $30-50 \%$, on average. On some nights, better agreement could be obtained by including in the model the uptake of $\mathrm{NO}_{3}$ and $\mathrm{N}_{2} \mathrm{O}_{5}$ on fog droplets, which was the dominant removal mechanism for $\mathrm{NO}_{3}$ and $\mathrm{N}_{2} \mathrm{O}_{5}$, when it was present.

The discrepancy between modelled and measured $\left[\mathrm{NO}_{3}\right]$ and $\left[\mathrm{N}_{2} \mathrm{O}_{5}\right]$ was studied as a function of different physical and chemical parameters as well as aerosol composition. The model generally performed better in photochemically young air masses and at lower [DMS], which suggests that part of the discrepancy might be related to uncertainties in the DMS mechanism. There was no clear correlation with aerosol composition, except for a weak dependence on nitrate content, which could also be related to the air mass age.

The model was tested to study the response of the chemical system to selected kinetic parameters, with particular focus on $\mathrm{N}_{2} \mathrm{O}_{5}$ reactivity. The model was run with and without homogeneous hydrolysis of $\mathrm{N}_{2} \mathrm{O}_{5}$ and with different values for the uptake coefficients and for the deposition rates of $\mathrm{NO}_{3}$ and $\mathrm{N}_{2} \mathrm{O}_{5}$. The results of these tests suggest that the reactive uptake coefficient on aerosol $(\gamma)$ was most likely $>1 \times 10^{-2}$ under most of the conditions encountered during the NEAQS 2004 cruise and that, if $\mathrm{N}_{2} \mathrm{O}_{5}$ does not hydrolyze in the gasphase, values of the order of $10^{-3}$ could be excluded.

The gas-phase chemistry of $\mathrm{NO}_{3}$ was studied in detail during some selected nights of the R/V Brown cruise to determine the most important $\mathrm{NO}_{3}$ losses under different chemical conditions. Some nights were dominated by $\mathrm{NO}_{3}+\mathrm{DMS}$ chemistry and others showed clear influence of biogenic or anthropogenic compounds. Organic peroxy radicals were shown to be significant gas-phase losses for $\mathrm{NO}_{3}$ : the median contribution of the reactions between $\mathrm{NO}_{3}$ and $\mathrm{RO}_{2}$ to the direct $\mathrm{NO}_{3}$ loss rate was $15 \%$ (the average was $19 \%$ ) and in some cases, such as when DMS controlled $\mathrm{NO}_{3}$ chemistry, these reactions were the second most important loss term for $\mathrm{NO}_{3}$ after the parent hydrocarbon.

The uncertainties surrounding $\mathrm{NO}_{3}$ and $\mathrm{N}_{2} \mathrm{O}_{5}$ losses, and in particular the homogeneous hydrolysis of $\mathrm{N}_{2} \mathrm{O}_{5}$ and the uptake coefficients of $\mathrm{NO}_{3}$ and $\mathrm{N}_{2} \mathrm{O}_{5}$, have been highlighted in this work and call for more studies on the field and in the laboratory in order to gain a better understanding of nighttime processes and their impact on the ozone and nitrogen budgets. The potential importance of peroxy radicals as $\mathrm{NO}_{3}$ sinks needs more investigation both in terms of determination of the rate coefficients and in terms of ability to measure individual peroxy radicals. 


\section{Appendix A}

\section{MCM nomenclature}

Table A1. MCM codenames and chemical structures of relevant species.

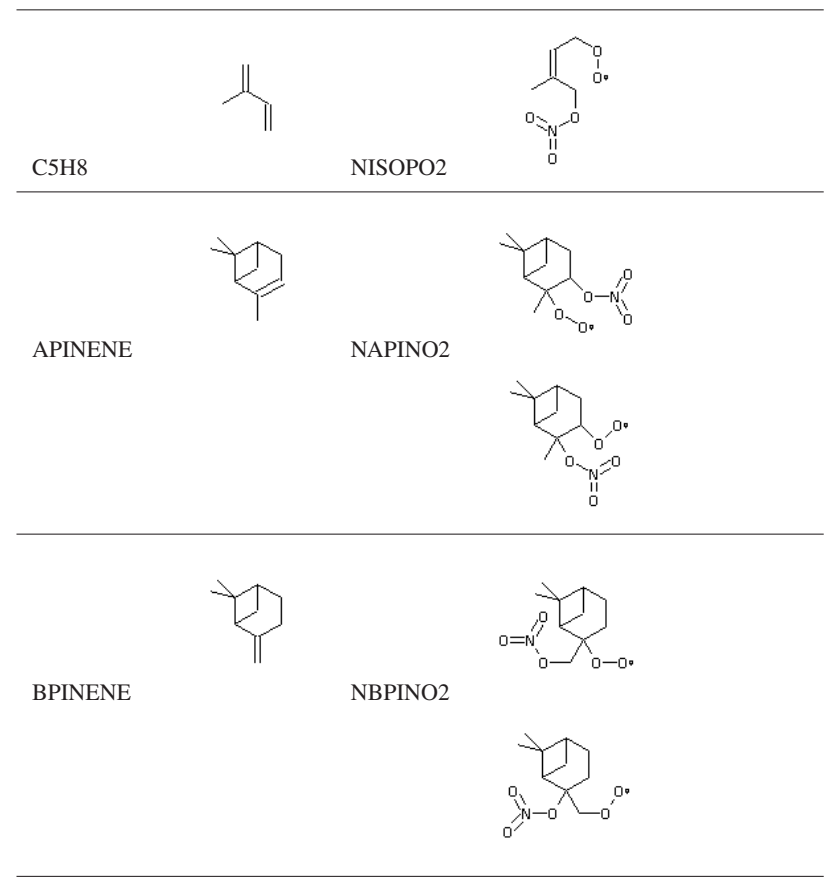

Acknowledgements. We would like to thank the crew of the NOAA R/V Brown for their help during the field campaign, D. T. Sueper for precious help with the analysis software and W. M. Angevine for useful discussions.

Edited by: J. Williams

\section{References}

Aldener, M., Brown, S. S., Stark, H., Williams, E. J., Lerner, B. M., Kuster, W. C., Goldan, P. D., Quinn, P. K., Bates, T. S., Fehsenfeld, F. C., and Ravishankara, A. R.: Reactivity and loss mechanisms of $\mathrm{NO}_{3}$ and $\mathrm{N}_{2} \mathrm{O}_{5}$ in a polluted marine environment: results from in situ measurements during New England Air Quality Study 2002, J. Geophys. Res., 111, D23S73, doi: 10.1029/2006JD007252, 2006.

Allan, B. J., Carslaw, N., Coe, H., Burgess, R. A., and Plane, J. M. C.: Observations of the nitrate radical in the marine boundary layer, J. Atmos. Chem., 33, 129-154, 1999.

Allan, B. J., McFiggans, G., Plane, J. M. C., Coe, H., and McFadyen, G. G.: The nitrate radical in the remote marine boundary layer, J. Geophys. Res., 105, 24191-24204, 2000.

Allan, B. J., Plane, J. M. C., Coe, H., and Shillito, J.: Observations of $\mathrm{NO}_{3}$ concentration profiles in the troposphere, J. Geophys. Res., 107, 4588, doi:10.1029/2002JD002112, 2002.

Ambrose, J. L., Mao, H., Mayne, H. R., Stutz, J., Talbot, R., and Sive, B. C.: Nighttime nitrate radical chemistry at Appledore Is- land, Maine during the 2004 International Consortium for Atmospheric Research on Transport and Transformation, J. Geophys. Res., 112, D21302, doi:10.1029/2007JD008756, 2007.

Angevine, W. M., Hare, J. E., Fairall, C. W., Wolfe, D. E., Hill, R. J., Brewer, W. A., and White, A. B.: Structure and formation of the highly stable marine boundary layer over the Gulf of Maine, J. Geophys. Res., 111, D23S22, doi:10.1029/2006JD007465, 2006.

Anttila, T., Kiendler-Schatt, A., Tillmann, R., and Mentel, T. F.: On the reactive uptake of gaseous compounds by organic-coated aqueous aerosols: theoretical analysis and application to the heterogeneous hydrolysis of $\mathrm{N}_{2} \mathrm{O}_{5}$, J. Phys. Chem. A, 110, 1043510443, 2006.

Atkinson, R. and Arey, J.: Atmospheric degradation of volatile organic compounds, Chem. Rev., 103, 4605-4638, 2003.

Atkinson, R., Baulch, D. L., Cox, R. A., Crowley, J. N., Hampson, R. F., Kerr, J. A., Rossi, M. J., and Troe, J.: Summary of evaluated kinetic and photochemical data for atmospheric chemistry, Tech. rep., IUPAC Subcommittee on Gas Kinetic Data Evaluation for Atmospheric Chemistry, http://www.iupac-kinetic.ch. cam.ac.uk, 2003.

Badger, C. L., Griffiths, P. T., George, I., Abbatt, J. P. D., and Cox, R. A.: Reactive uptake of $\mathrm{N}_{2} \mathrm{O}_{5}$ by aerosol particles containing mixtures of humic acid and ammonium sulfate, J. Phys. Chem. A, 110, 6986-6994, 2006.

Barnes, I., Hjorth, J., and Mihalopoulos, N.: Dimethyl sulfide and dimethyl sulfoxide and their oxidation in the atmosphere, Chem. Rev., 106, 940-975, 2006.

Baynard, T., Lovejoy, E. R., Pettersson, A., Brown, S. S., Lack, D., Osthoff, H., Massoli, P., Ciciora, S., Dubé, W. P., and Ravishankara, A. R.: Design and application of a pulsed cavity ringdown aerosol extinction spectrometer for field measurements, Aerosol Sci. Technol., 41, 447-462, 2007.

Bey, I., Aumont, B., and Toupance, G.: A modeling study of the nighttime radical chemistry in the lower continental troposphere -2 . Origin and evolution of $\mathrm{HO}_{\mathrm{x}}$, J. Geophys. Res., 106, 999110001, 2001.

Brown, S. S., Stark, H., and Ravishankara, A. R.: Applicability of the steady state approximation to the interpretation of atmospheric observations of $\mathrm{NO}_{3}$ and $\mathrm{N}_{2} \mathrm{O}_{5}$, J. Geophys. Res., 108, 4539, doi:10.1029/2003JD003407, 2003a.

Brown, S. S., Stark, H., Ryerson, T. B., Williams, E. J., Nicks, D. K., Trainer, M., Fehsenfeld, F. C., and Ravishankara, A. R.: Nitrogen oxides in the nocturnal boundary layer: simultaneous in situ measurements of $\mathrm{NO}_{3}, \mathrm{~N}_{2} \mathrm{O}_{5}, \mathrm{NO}_{2}$, $\mathrm{NO}$ and $\mathrm{O}_{3}$, J. Geophys. Res., 108, 4299, doi:10.1029/2002JD002917, 2003b.

Brown, S. S., Dibb, J. E., Stark, H., Aldener, M., Vozella, M., Whitlow, S., Williams, E. J., Lerner, B. M., Jakoubek, R., Middlebrook, A. M., de Gouw, J. A., Warneke, C., Goldan, P. D., Kuster, W. C., Angevine, W. M., Sueper, D. T., Quinn, P. K., Bates, T. S., Meagher, J. F., Fehsenfeld, F. C., and Ravishankara, A. R.: Nighttime removal of $\mathrm{NO}_{\mathrm{x}}$ in the summer marine boundary layer, Geophys. Res. Lett., 31, L07108, doi:10.1029/2004GL019412, 2004.

Brown, S. S., Ryerson, T. B., Wollny, A. G., Brock, C. A., Peltier, R., Sullivan, A. P., Weber, R. J., Holloway, J. S., Dubé, W. P., Trainer, M., Meagher, J. F., Fehsenfeld, F. C., and Ravishankara, A. R.: Variability in nocturnal nitrogen oxide processing and its role in regional air quality, Science, 311, 67-70, 2006. 
Brown, S. S., Dubé, W. P., Osthoff, H. D., Stutz, J., Ryerson, T. B., Wollny, A. G., Brock, C. A., Warneke, C., de Gouw, J. A., Atlas, E., Neuman, J. A., Holloway, J. S., Lerner, B. M., Williams, E. J., Kuster, W. C., Goldan, P. D., Angevine, W. M., Trainer, M., Fehsenfeld, F. C., and Ravishankara, A. R.: Vertical profiles in $\mathrm{NO}_{3}$ and $\mathrm{N}_{2} \mathrm{O}_{5}$ measured from an aircraft: results from the NOAA P-3 and surface platforms during the New England Air Quality Study 2004, J. Geophys. Res., 112, D22304, doi: 10.1029/2007JD008883, 2007a.

Brown, S. S., Dubé, W. P., Osthoff, H. D., Wolfe, D. E., Angevine, W. M., and Ravishankara, A. R.: High resolution vertical distributions of $\mathrm{NO}_{3}$ and $\mathrm{N}_{2} \mathrm{O}_{5}$ through the nocturnal boundary layer, Atmos. Chem. Phys., 7, 139-149, 2007b,

http://www.atmos-chem-phys.net/7/139/2007/.

Canosa-Mas, C. E., King, M. D., Lopez, R., Percival, C. J., Wayne, R. P., Shallcross, D. E., Pyle, J. A., and Daële, V.: Is the reaction between $\mathrm{CH}_{3} \mathrm{C}(\mathrm{O}) \mathrm{O}_{2}$ and $\mathrm{NO}_{3}$ important in the night-time troposphere?, J. Chem. Soc. - Faraday Transactions, 92, 22112222, doi:10.1039/FT9969202211, 1996.

Cantrell, C. A., Shetter, R. E., Calvert, J. G., Eisele, F. L., and Tanner, D.: Some considerations of the origin of nighttime peroxy radicals observed in MLOPEX 2c, J. Geophys. Res., 102, 1589915913, 1997.

Carslaw, N., Carpenter, L. J., Plane, J. M. C., Allan, B. J., Burgess, R. A., Clemitshaw, K. C., Coe, H., and Penkett, S. A.: Simultaneous observations of nitrate and peroxy radicals in the marine boundary layer, J. Geophys. Res., 102, 18917-18933, 1997.

Carslaw, N., Creasey, D. J., Heard, D. E., Lewis, A. C., McQuaid, J. B., Pilling, M. J., Monks, P. S., Bandy, B. J., and Penkett, S. A.: Modeling $\mathrm{OH}, \mathrm{HO}_{2}$, and $\mathrm{RO}_{2}$ radicals in the marine boundary layer - 1. Model construction and comparison with field measurements, J. Geophys. Res., 104, 30241-30255, 1999.

Carslaw, N., Jacobs, P. J., and Pilling, M. J.: Understanding radical chemistry in the marine boundary layer, Physics and Chemistry of the Earth - Sol.-Terr. Planet. Sci., 25, 235-243, 2000.

Carslaw, N., Creasey, D. J., Heard, D. E., Jacobs, P. J., Lee, J. D., Lewis, A. C., McQuaid, J. B., Pilling, M. J., Bauguitte, S., Penkett, S. A., Monks, P. S., and Salisbury, G.: Eastern Atlantic Spring Experiment 1997 (EASE97) - 2. Comparisons of model concentrations of $\mathrm{OH}, \mathrm{HO}_{2}$, and $\mathrm{RO}_{2}$ with measurements, J. Geophys. Res., 107, 4190, doi:10129/2001JD001568, 2002.

Cruz, C. N. and Pandis, S. N.: Deliquescence and hygroscopic growth of mixed inorganic-organic atmospheric aerosol, Environ. Sci. Technol., 34, 4313-4319, 2000.

Davis, J. M., Bhave, P. V., and Foley, K. M.: Parameterization of $\mathrm{N}_{2} \mathrm{O}_{5}$ reaction probabilities on the surface of particles containing ammonium, sulfate, and nitrate, Atmos. Chem. Phys., 8, 52955311, 2008, http://www.atmos-chem-phys.net/8/5295/2008/.

Dubé, W. P., Brown, S. S., Osthoff, H. D., Nunley, M. R., Ciciora, S. J., Paris, M. W., McLaughlin, R. J., and Ravishankara, A. R.: Aircraft instrument for simultaneous, in situ measurement of $\mathrm{NO}_{3}$ and $\mathrm{N}_{2} \mathrm{O}_{5}$ via pulsed cavity ring-down spectroscopy, Rev. Sci. Instr., 77, 034101, 2006.

Ehhalt, D. H. and Rohrer, F.: Dependence of the $\mathrm{OH}$ concentration on solar UV, J. Geophys. Res., 105, 3565-3572, 2000.

Emmerson, K. M., Carslaw, N., Carslaw, D. C., Lee, J. D., McFiggans, G., Bloss, W. J., Gravestock, T., Heard, D. E., Hopkins, J., Ingham, T., Pilling, M. J., Smith, S. C., Jacob, M., and Monks, P. S.: Free radical modelling studies during the UK TORCH cam- paign in summer 2003, Atmos. Chem. Phys., 7, 167-181, 2007, http://www.atmos-chem-phys.net/7/167/2007/.

Fehsenfeld, F. C., Ancellet, G., Bates, T. S., Goldstein, A. H., Hardesty, R. M., Honrath, R., Law, K. S., Lewis, A. C., Leaitch, R., McKeen, S., Meagher, J., Parrish, D. D., Pszenny, A. A. P., Russel, P. B., Schlager, H., Seinfeld, J., Talbot, R., and Zbinden, R.: International Consortium for Atmospheric Research on Transport and Transformation (ICARTT): North America to Europe Overview of the 2004 summer field study, J. Geophys. Res., 111, D23S01, doi:10.1029/2006JD007829, 2006.

Fleming, Z. L., Monks, P. S., Rickard, A. R., Heard, D. E., Bloss, W. J., Seakins, P. W., Still, T. J., Sommariva, R., Pilling, M. J., Morgan, R., Green, T. J., Brough, N., Mills, G. P., Penkett, S. A., Lewis, A. C., Lee, J. D., Saiz-Lopez, A., and Plane, J. M. C.: Peroxy radical chemistry and the control of ozone photochemistry at Mace Head, Ireland during the summer of 2002, Atmos. Chem. Phys., 6, 2193-2214, 2006, http://www.atmos-chem-phys.net/6/2193/2006/.

Folkers, M., Mentel, T. F., and Wahner, A.: Influence of an organic coating on the reactivity of aqueous aerosols probed by the heterogeneous hydrolysis of $\mathrm{N}_{2} \mathrm{O}_{5}$, Geophys. Res. Lett., 30, 1644, doi:10.1029/2003GL017168, 2003.

Fuchs, N. A. and Sutugin, A. G.: Highly dispersed aerosols, Ann Arbor Science, Ann Arbor, MI, USA, 1970.

Geyer, A. and Stutz, J.: Vertical profiles of $\mathrm{NO}_{3}, \mathrm{~N}_{2} \mathrm{O}_{5}, \mathrm{O}_{3}$ and $\mathrm{NO}_{\mathrm{x}}$ in the nocturnal boundary layer: 2. Model studies on the altitude dependence of composition and chemistry, J. Geophys. Res., 109, D12307, doi:10.1029/2003JD004211, 2004.

Geyer, A., Bächmann, K., Hofzumahaus, A., Holland, F., Konrad, S., Klüpfel, T., Pätz, A.-W., Perner, D., Mihelcic, D., Schäfer, H.-J., Volz-Thomas, A., and Platt, U.: Nighttime formation of peroxy radicals during the BERLIOZ campaign: observations and modeling studies, J. Geophys. Res., 108, 8249, doi: 10.1029/2001JD000656, 2003.

Goldan, P. D., Kuster, W. C., Williams, E., Murphy, P. C., Fehsenfeld, F. C., and Meagher, J.: Nonmethane hydrocarbon and oxy hydrocarbon measurements during the 2002 New England Air Quality Study, J. Geophys. Res., 109, D21309, doi:10.1029/ 2003JD004455, 2004.

Hallquist, M., Stewart, D. J., Stephenson, S. K., and Cox, R. A.: Hydrolysis of $\mathrm{N}_{2} \mathrm{O}_{5}$ on sub-micron sulfate aerosol, Phys. Chem. Chem. Phys., 5, 3453-3463, 2003.

Hanisco, T. F., Lanzendorf, E. J., Wennberg, P. O., Perkins, K. K., Stimpfle, R. M., Voss, P. B., Anderson, J. G., Cohen, R. C., Fahey, D. W., Gao, R. S., Hintsa, E. J., Salawitch, R. J., Margitan, J. J., McElroy, C. T., and Midwinter, C.: Sources, sinks, and the distribution of $\mathrm{OH}$ in the lower stratosphere, J. Phys. Chem. A, 105, 1543-1553, 2001.

Heard, D. E., Read, K. A., Methven, J., Al-Haider, S., Bloss, W. J., Johnson, G. P., Pilling, M. J., Seakins, P. W., Smith, S. C., Sommariva, R., Stanton, J. C., Still, T. J., Ingham, T., Brooks, B., De Leeuw, G., Jackson, A. V., McQuaid, J. B., Morgan, R., Smith, M. H., Carpenter, L. J., Carslaw, N., Hamilton, J., Hopkins, J. R., Lee, J. D., Lewis, A. C., Purvis, R. M., Wevill, D. J., Brough, N., Green, T., Mills, G., Penkett, S. A., Plane, J. M. C., Saiz-Lopez, A., Worton, D., Monks, P. S., Fleming, Z., Rickard, A. R., Alfarra, M. R., Allan, J. D., Bower, K., Coe, H., Cubison, M., Flynn, M., McFiggans, G., Gallagher, M., Norton, E. G., O’Dowd, C. D., Shillito, J., Topping, D., Vaughan, G., Williams, 
P., Bitter, M., Ball, S. M., Jones, R. L., Povey, I. M., O’Doherty, S., Simmonds, P. G., Allen, A., Kinnersley, R. P., Beddows, D. C. S., Dall'Osto, M., Harrison, R. M., Donovan, R. J., Heal, M. R., Jennings, S. G., Noone, C., and Spain, G.: The North Atlantic Marine Boundary Layer Experiment(NAMBLEX). Overview of the campaign held at Mace Head, Ireland, in summer 2002, Atmos. Chem. Phys., 6, 2241-2272, 2006,

http://www.atmos-chem-phys.net/6/2241/2006/.

$\mathrm{Hu}$, J. H. and Abbatt, J. P. D.: Reaction probabilities for $\mathrm{N}_{2} \mathrm{O}_{5}$ hydrolysis on sulfuric acid and ammonium sulfate aerosols at room temperature, J. Phys. Chem. A, 101, 871-878, 1997.

Jenkin, M. E., Clement, C. F., and Ford, I. J.: Gas-to-particle conversion pathways, First Annual Report Met2a/1053/Project 2, AEA Technology, 1996.

Jenkin, M. E., Saunders, S. M., and Pilling, M. J.: The tropospheric degradation of volatile organic compounds: a protocol for mechanism development, Atmos. Environ., 31, 81-104, 1997.

Jenkin, M. E., Saunders, S. M., Wagner, V., and Pilling, M. J.: Protocol for the development of the Master Chemical Mechanism, MCM v3 (Part B): tropospheric degradation of aromatic volatile organic compounds, Atmos. Chem. Phys., 3, 181-193, 2003, http://www.atmos-chem-phys.net/3/181/2003/.

Jones, R. L., Ball, S. M., and Shallcross, D. E.: Small scale structure in the atmosphere: implications for chemical composition and observational methods, Faraday Discuss., 130, 165-179, 2005.

Kane, S. M., Caloz, F., and Leu, M.-T.: Heterogeneous uptake of gaseous $\mathrm{N}_{2} \mathrm{O}_{5}$ by $\left(\mathrm{NH}_{4}\right)_{2} \mathrm{SO}_{4}, \mathrm{NH}_{4} \mathrm{HSO}_{4}$ and $\mathrm{H}_{2} \mathrm{SO}_{4}$ aerosols, J. Phys. Chem. A, 105, 6465-6470, 2001.

Koga, S. and Tanaka, H.: Numerical study of the oxidation process of dimethylsulfide in the marine atmosphere, J. Atmos. Chem., 17, 201-228, 1993.

Mak, J., Gross, S., and Bertram, A. K.: Uptake of $\mathrm{NO}_{3}$ on soot and pyrene surfaces, Geophys. Res. Lett., 34, L10804, doi:10.1029/ 2006GL029756, 2007.

McNeill, V. F., Patterson, J., Wolfe, G. M., and Thornton, J. A.: The effect of varying levels of surfactant on the reactive uptake of $\mathrm{N}_{2} \mathrm{O}_{5}$ to aqueous aerosol, Atmos. Chem. Phys., 6, 1635-1644, 2006, http://www.atmos-chem-phys.net/6/1635/2006/.

Mentel, T. F., Bleilebens, D., and Wahner, A.: A study of nighttime nitrogen oxide oxidation in a large reaction chamber - The fate of $\mathrm{NO}_{2}, \mathrm{~N}_{2} \mathrm{O}_{5}, \mathrm{HNO}_{3}$, and $\mathrm{O}_{3}$ at different humidities, Atmos. Environ., 30, 4007-4020, 1996.

Mentel, T. F., Sohn, M., and Wahner, A.: Nitrate effect in the heterogeneous hydrolysis of dinitrogen pentoxide on aqueous aerosols, Phys. Chem. Chem. Phys., 1, 5451-5457, 1999.

Mihelcic, D., Klemp, D., Müsgen, P., Pätz, H. W., and VolzThomas, A.: Simultaneous measurements of peroxy and nitrate radicals at Schauinsland, J. Atmos. Chem., 16, 313-335, 1993.

Osthoff, H. D., Sommariva, R., Baynard, T., Pettersson, A., Williams, E. J., Lerner, B. M., Roberts, J. M., Stark, H., Goldan, P. D., Kuster, W. C., Bates, T. S., Coffman, D., Ravishankara, A. R., and Brown, S. S.: Observation of daytime $\mathrm{N}_{2} \mathrm{O}_{5}$ in the marine boundary layer during New England Air Quality StudyIntercontinental Transport and Chemical Transformation 2004, J. Geophys. Res., 111, D23S14, doi:10.1029/2006JD007593, 2006.

Osthoff, H. D., Pilling, M. J., Ravishankara, A. R., and Brown, S. S.: Temperature dependence of the $\mathrm{NO}_{3}$ absorption crosssection above $298 \mathrm{~K}$ and determination of the equilibrium con- stant for $\mathrm{NO}_{3}+\mathrm{NO}_{2} \leftrightarrow \mathrm{N}_{2} \mathrm{O}_{5}$ at atmospherically relevant conditions, Phys. Chem. Chem. Phys., 9, 5785-5793, 2007.

Osthoff, H. D., Bates, T. S., Johnson, J. E., Kuster, W. C., Goldan, P., Sommariva, R., Williams, E. J., Lerner, B. M., Warneke, C., de Gouw, J. A., Pettersson, A., Baynard, T., Meagher, J. F., Fehsenfeld, F. C., Ravishankara, A. R., and Brown, S. S.: Regional variation of the dimethyl sulfide oxidation mechanism in the summertime marine boundary layer in the Gulf of Maine, J. Geophys. Res., 114, D07301, doi:10.1029/2008JD010990, 2009.

Park, S.-C., Burden, D. K., and Nathanson, G. M.: The inhibition of $\mathrm{N}_{2} \mathrm{O}_{5}$ hydrolysis in sulfuric acid by 1-butanol and 1-hexanol surfactant coatings, J. Phys. Chem. A, 111, 2921-2929, 2007.

Platt, U., LeBras, G., Poulet, G., Burrows, J. P., and Moortgat, G.: Peroxy-radicals from nighttime reaction of $\mathrm{NO}_{3}$ with organic compounds, Nature, 348, 147-149, 1990.

Platt, U., Alicke, B., Dubois, R., Geyer, A., Hofzumahaus, A., Holland, F., Martinez, M., Mihelcic, D., Klüpfel, T., Lohrmann, B., Pätz, W., Perner, D., Rohrer, F., Schäfer, J., and Stutz, J.: Free radicals and fast photochemistry during BERLIOZ, J. Atmos. Chem., 42, 359-394, 2002.

Platt, U. F., Winer, A. M., Biermann, H. W., Atkinson, R., and Pitts, J. N.: Measurement of nitrate radical concentrations in continental air, Environ. Sci. Technol., 18, 365-369, 1984.

Quinn, P. K., Bates, T. S., Coffman, D., Onasch, T. B., Worsnop, D., Baynard, T., de Gouw, J. A., Goldan, P. D., Kuster, W. C., Williams, E., Roberts, J. M., Lerner, B., Stohl, A., Pettersson, A., and Lovejoy, E. R.: Impacts of sources and aging on submicrometer aerosol properties in the marine boundary layer across the Gulf of Maine, J. Geophys. Res., 111, D23S36, doi: 10.1029/2006JD007582, 2006.

Rohrer, F. and Berresheim, H.: Strong correlation between levels of tropospheric hydroxyl radicals and solar ultraviolet radiation, Nature, 442, 184-187, 2006.

Rudich, Y., Talukdar, R. K., and Ravishankara, A. R.: Reactive uptake of $\mathrm{NO}_{3}$ on pure water and ionic solutions, J. Geophys. Res., 101, 21 023-21 031, 1996.

Salisbury, G., Rickard, A. R., Monks, P. S., Allan, B. J., Bauguitte, S., Penkett, S. A., Carslaw, N., Lewis, A. C., Creasey, D. J., Heard, D. E., Jacobs, P. J., and Lee, J. D.: Production of peroxy radicals at night via reactions of ozone and the nitrate radical in the marine boundary layer, J. Geophys. Res., 106, 12669-12687, 2001.

Saunders, S. M., Jenkin, M. E., Derwent, R. G., and Pilling, M. J.: Protocol for the development of the Master Chemical Mechanism, MCM v3 (Part A): tropospheric degradation of nonaromatic volatile organic compounds, Atmos. Chem. Phys., 3, 161-180, 2003, http://www.atmos-chem-phys.net/3/161/2003/.

Savage, N. H., Harrison, R. M., Monks, P. S., and Salisbury, G.: Steady-state modelling of hydroxyl radical concentrations at Mace Head during the EASE'97 campaign, May 1997, Atmos. Environ., 35, 515-524, 2001.

Sommariva, R., Haggerstone, A.-L., Carpenter, L. J., Carslaw, N., Creasey, D. J., Heard, D. E., Lee, J. D., Lewis, A. C., Pilling, M. J., and Zádor, J.: $\mathrm{OH}$ and $\mathrm{HO}_{2}$ chemistry in clean marine air during SOAPEX-2, Atmos. Chem. Phys., 4, 839-856, 2004, http://www.atmos-chem-phys.net/4/839/2004/.

Sommariva, R., Bloss, W. J., Brough, N., Carslaw, N., Flynn, M., Haggerstone, A.-L., Heard, D. E., Hopkins, J. R., Lee, J. D., Lewis, A. C., McFiggans, G., Monks, P. S., Penkett, S. A., 
Pilling, M. J., Plane, J. M. C., Read, K. A., Saiz-Lopez, A., Rickard, A. R., and Williams, P. I.: $\mathrm{OH}$ and $\mathrm{HO}_{2}$ chemistry during NAMBLEX: roles of oxygenates, halogen oxides and heterogeneous uptake, Atmos. Chem. Phys., 6, 1135-1153, 2006, http://www.atmos-chem-phys.net/6/1135/2006/.

Sommariva, R., Pilling, M. J., Bloss, W. J., Heard, D. E., Lee, J. D., Fleming, Z. L., Monks, P. S., Plane, J. M. C., Saiz-Lopez, A., Ball, S. M., Bitter, M., Jones, R. L., Brough, N., Penkett, S. A., Hopkins, J. R., Lewis, A. C., and Read, K. A.: Night-time radical chemistry during the NAMBLEX campaign, Atmos. Chem. Phys., 7, 587-598, 2007,

http://www.atmos-chem-phys.net/7/587/2007/.

Stark, H., Brown, S. S., Goldan, P. D., Aldener, M., Kuster, W. C., Jakoubek, R., Fehsenfeld, F. C., Meagher, J., Bates, T. S., and Ravishankara, A. R.: Influence of nitrate radical on the oxidation of dimethyl sulfide in a polluted marine environment, J. Geophys. Res., 112, D10S10, doi:10.1029/2006JD007669, 2007.

Still, T. J., Al-Haider, S., Seakins, P. W., Sommariva, R., Stanton, J. C., Mills, G., and Penkett, S. A.: Ambient formaldehyde measurements made at a remote marine boundary layer site during the NAMBLEX campaign - a comparison of data from chromatographic and modified Hantzsch techniques, Atmos. Chem. Phys., 6, 2711-2726, 2006,

http://www.atmos-chem-phys.net/6/2711/2006/.

Stutz, J., Alicke, B., Ackermann, R., Geyer, A., White, A., and Williams, E.: Vertical profiles of $\mathrm{NO}_{3}, \mathrm{~N}_{2} \mathrm{O}_{5}, \mathrm{O}_{3}$, and $\mathrm{NO}_{\mathrm{x}}$ in the nocturnal boundary layer: 1 . Observations during the Texas Air Quality Study 2000, J. Geophys. Res., 109, D12306, doi: 10.1029/2003JD004209, 2004.

Tang, I.: Thermodynamic and optical properties of sea salt aerosols, J. Geophys. Res., 102, 23269-23275, 1997.

Thomas, K., Volz-Thomas, A., Mihelcic, D., Smit, H. G. J., and Kley, D.: On the exchange of $\mathrm{NO}_{3}$ radicals with aqueous solutions: solubility and sticking coefficient, J. Atmos. Chem., 29, 17-43, 1998.

Thornton, J. A., Braban, C. F., and Abbatt, J. P. D.: $\mathrm{N}_{2} \mathrm{O}_{5}$ hydrolysis on sub-micron organic aerosols: the effect of relative humidity, particle phase and particle size, Phys. Chem. Chem. Phys., 5, 4593-4603, 2003.

Turnipseed, A. A., Barone, S. B., and Ravishankara, A. R.: Reaction of $\mathrm{OH}$ with dimethyl sulfide -2 . Products and mechanism, J. Phys. Chem., 100, 14703-14713, 1996.

VanDoren, J. M., Watson, L. R., Davidovits, P., Worsnop, D. R., Zahniser, M. S., and Kolb, C. E.: Temperature dependence of the uptake coefficients of nitric acid, hydrochloric acid and nitrogen oxide $\left(\mathrm{N}_{2} \mathrm{O}_{5}\right)$ by water droplets, J. Phys. Chem., 94, 3265-3269, 1990.

Vaughan, S., Canosa-Mas, C. E., Pfrang, C., Shallcross, D. E., Watson, L., and Wayne, R. P.: Kinetic studies of reactions of the nitrate radical $\left(\mathrm{NO}_{3}\right)$ with peroxy radicals $\left(\mathrm{RO}_{2}\right)$ : an indirect source of $\mathrm{OH}$ at night?, Phys. Chem. Chem. Phys., 8, 3749-3760, 2006.
Voegele, A. F., Tautermann, C. S., Loerting, T., and Liedl, K. R.: Toward elimination of discrepancies between theory and experiment: the gas-phase reaction of $\mathrm{N}_{2} \mathrm{O}_{5}$ with $\mathrm{H}_{2} \mathrm{O}$, Phys. Chem. Chem. Phys., 5, 487-495, 2003.

Vrekoussis, M., Kanakidou, M., Mihalopoulos, N., Crutzen, P. J., Lelieveld, J., Berresheim, D. P. H., and Baboukas, E.: Role of the $\mathrm{NO}_{3}$ radicals in oxidation processes in the Eastern Mediterranean troposphere during the MINOS campaign, Atmos. Chem. Phys., 4, 169-182, 2004,

http://www.atmos-chem-phys.net/4/169/2004/.

Wahner, A., Mentel, T. F., and Sohn, M.: Gas-phase reaction of $\mathrm{N}_{2} \mathrm{O}_{5}$ with water vapor: importance of heterogeneous hydrolysis of $\mathrm{N}_{2} \mathrm{O}_{5}$ and surface desorption of $\mathrm{HNO}_{3}$ in a large teflon chamber, Geophys. Res. Lett., 25, 2169-2172, 1998.

Warneke, C., de Gouw, J. A., Goldan, P. D., Kuster, W. C., Williams, E. J., Lerner, B. M., Jakoubek, R., Brown, S. S., Stark, H., Aldener, M., Ravishankara, A. R., Roberts, J. M., Marchewka, M., Bertman, S., Sueper, D. T., McKeen, S. A., Meagher, J. F., and Fehsenfeld, F. C.: Comparison of daytime and nighttime oxidation of biogenic and anthropogenic VOCs along the New England coast in summer during New England Air Quality Study 2002, J. Geophys. Res., 109, D10309, doi: 10.1029/2003JD004424, 2004.

Warneke, C., Kato, S., de Gouw, J. A., Goldan, P. D., Kuster, W. C., Shao, M., Lovejoy, E. R., Fall, R., and Fehsenfeld, F. C.: Online volatile organic compound measurements using a newly developed proton-transfer ion-trap mass spectrometry instrument during New England Air Quality Study-Intercontinental Transport and Chemical Transformation 2004: performance, intercomparison, and compound identification, Environ. Sci. Technol., 39, 5390-5397, 2005.

Warneke, C., de Gouw, J. A., Stohl, A., Cooper, O. R., Goldan, P. D., Kuster, W. C., Holloway, J. S., Williams, E. J., Lerner, B. M., McKeen, S. A., Trainer, M., Fehsenfeld, F. C., Atlas, E. L., Donnelly, S. G., Stroud, V., Lueb, A., and Kato, S.: Biomass burning and anthropogenic sources of CO over New England in the summer 2004, J. Geophys. Res., 111, D23S15, doi:10.1029/ 2005JD006878, 2006.

Wayne, R. P., Barnes, I., Biggs, P., Burrows, J. P., Canosa-Mas, C. E., Hjorth, J., LeBras, G., Moortgat, G. K., Perner, D., Poulet, G., Restelli, G., and Sidebottom, H.: The nitrate radical - Physics, chemistry, and the atmosphere, Atmos. Environ., 25, 1-203, 1991.

Yin, F. D., Grosjean, D., and Seinfeld, J. H.: Photooxidation of dimethyl sulfide and dimethyl disulfide -1 . Mechanism development, J. Atmos. Chem., 11, 309-364, 1990a.

Yin, F. D., Grosjean, D., Flagan, R. C., and Seinfeld, J. H.: Photooxidation of dimethyl sulfide and dimethyl disulfide -2 . Mechanism evaluation, J. Atmos. Chem., 11, 365-399, 1990 b. 